\title{
Quellen- und Literaturverzeichnis
}

\section{A Unveröffentlichte schriftliche Quellen}

\section{A.1 Archive}

\section{Bundesarchiv Berlin (BArch Berlin)}

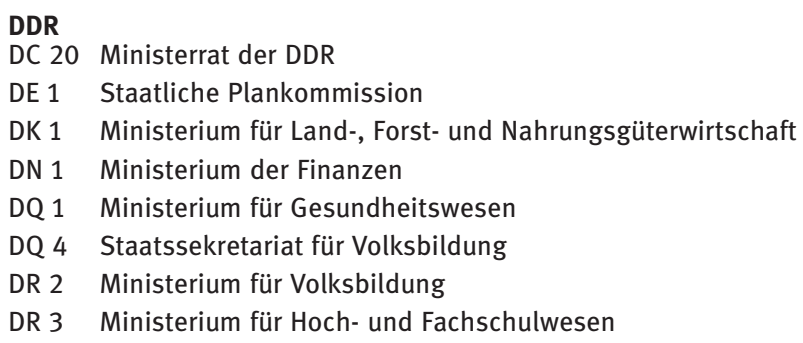

Stiftung Archiv der Parteien und Massenorganisation der DDR (SAPMO) DY 13 Liga für Völkerfreundschaft

DY 24 Freie Deutsche Jugend

DY 30 Sozialistische Einheitspartei Deutschlands

DY 34 Freier Deutscher Gewerkschaftsbund

DZ 8 Solidaritätskomitee der DDR

\section{Bundesarchiv Koblenz (BArch Koblenz)}

B 102 Bundesministerium für Wirtschaft

B 138 Bundesministerium für Bildung und Wissenschaft

B 213 Bundesministerium für Wirtschaftliche Zusammenarbeit

Bundesbeauftragter für die Unterlagen des Staatssicherheitsdienstes der ehemaligen DDR, Zentralstelle Berlin (BStU)

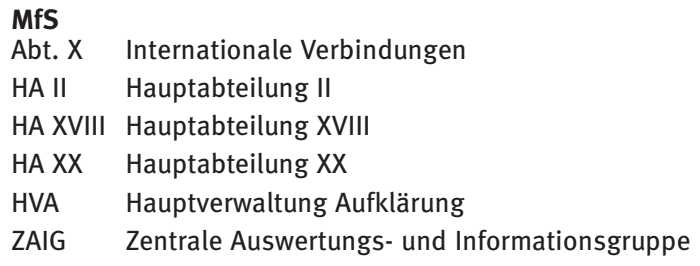


Bundesministerium für Wirtschaftliche Zusammenarbeit, Bonn (BMZ)

Die eingesehenen Akten befanden sich während der Forschung im Zwischenarchiv und wurden im BMZ eingesehen. Sie werden zukünftig in das Bundesarchiv Koblenz überführt.

B 213 Bundesministerium für Wirtschaftliche Zusammenarbeit

\title{
Chama cha Mapinduzi Archiv, Dodoma (CCMA)
}

Ein Überblicksverzeichnis lag nicht vor. Die Signaturen bzw. Titel in den Fußnoten geben daher die Angaben auf den Deckblättern der Akten wieder.

\section{Deutscher Akademischer Austauschdienst, Bonn (DAAD-Archiv)}

Die eingesehenen Akten befanden sich während der Forschung im Zwischenarchiv und wurden beim DAAD eingesehen. Sie werden zukünftig in das Bundesarchiv Koblenz überführt.

B 212 Deutscher Akademischer Austauschdienst

\section{Hessisches Hauptstaatsarchiv Wiesbaden (HHStAW)}

507 Entwicklungshilfe

Politisches Archiv des Auswärtigen Amtes, Berlin (PAAA)

Signaturen ZR (MFAA) bzw. ZW (BRD) verweisen auf Akten im Zwischenarchiv.

\section{Ministerium für Auswärtige Angelegenheiten der DDR (MfAA)}

Abteilung Afrika

Neues Amt (BRD)

BRD-Botschaft Dar es Salaam

B 34 Politische Abteilung

B 58 Entwicklungshilfe

\section{Tanzania National Archives, Dar es Salaam (TNA)}

562 Regional Office Tanga

597 Wizara ya Mambo ya Nje (Außenministerium)

\section{Universitätsarchiv Leipzig (UAL)}

Akten mit der Signatur ZM befinden sich im Zwischenarchiv, gehören aber zu den angegebenen Beständen.

\author{
DIB Direktorat für internationale Beziehungen \\ DKQ Direktorat für Kader und Qualifizierung \\ R Rektorat \\ StuA Studentenakten \\ WR Promotionsakten
}




\section{A.2 Online-Archive}

Wilson Center Digital Archive (http://digitalarchive.wilsoncenter.org/)

Wikileaks (https://wikileaks.org/)

\section{A.3 Sammlungen/Bibliotheken}

\section{East Africana Collection, Universität Dar es Salaam (EAC)}

Hier wurden u.a. wissenschaftliche Studien, die jährlichen Manpower Reports der Vereinigten Republik Tansania sowie die Jahresberichte (Activity Reports) und Vorlesungsverzeichnisse (Calendar) der Universität Dar es Salaam eingesehen. Akademische Studien sind weiter unten („Unveröffentlichte akademische Qualifikationsarbeiten“) gelistet.

Ngware, S. S. A. /B. C. Nindi, Sociological Study: „Soil Erosion Control, Agroforestry Project, and Livestock Development in the Western Usambaras“, Dar es Salaam 1982

URT, Annual Manpower Report (Jahrgänge 1968-1987)

UDSM, Activity Report (Jahrgänge 1970/71-1989/90)

UDSM, Calendar (Jahrgänge 1973-1988)

\section{Archivsektion der Stadtbibliothek Tanga (Tanga Library)}

Die Materialien der alten TIRDEP-Projektbibliothek wurden in den 1990er Jahren in die Stadtbibliothek überführt und bilden dort eine eigene, frei zugängliche Sektion. Hier finden sich neben Vorstudien, Evaluationen und Projektberichten aus den einzelnen TIRDEP-Vorhaben auch eine Reihe veröffentlichter und unveröffentlichter Schriftquellen zur Entwicklungszusammenarbeit. Alle eingesehenen Titel sind in den Fußnoten mit der jeweiligen Signatur bzw. dem Namen des Ordners angegeben.

\section{A.4 Archive von Privatpersonen}

Zahlreiche InterviewpartnerInnen haben Einblick in vereinzelte Dokumente gewährt und Fotos von ihrer Zeit während des Auslandsaufenthalts gezeigt bzw. überlassen. In drei Fällen wurden umfassendere Sammlungen zugänglich gemacht.

Privatarchiv Awadhi Mawenya, Dar es Salaam

Privatarchiv S. R., Tanga

Privatarchiv E. W., Werneuchen 


\section{A.5 Unveröffentlichte akademische Qualifikationsarbeiten und Manuskripte}

Altorfer-Ong, Alicia, Old Comrades and New Brothers: A Historical Re-Examination of the SinoZanzibari and Sino-Tanzanian Bilateral Relationships in the 1960s, PhD Thesis, London 2014

Bourbonniere, Michelle Elise, Debating Socialism on the Hill. The University of Dar es Salaam, 1961-1971, MA Thesis, Halifax, N.S. 2007

Braseby, Anne M., Adaptation of Trailing Spouses: Does Gender Matter?, PhD Thesis, Miami 2010

Burton, Eric, Development Concepts of Peasants, Poets and Dancers in German East Africa ca. 1870-1918, Diplomarbeit, Wien 2013

Harisch, Immanuel, Walter Rodney's Dar es Salaam Years, 1966-1974: How Europe Underdeveloped Africa, Tanzania’s Ujamaa, and Student Radicalism at „the Hill“', Masterarbeit, Wien, 2017

Katsakioris, Constantin, Leçons soviétiques: la formation des étudiants africains et arabes en URSS pendant la guerre froide, PhD Dissertation, Paris 2015

Kleemeier, Lizz Lyle, Integrated Rural Development in Tanzania: The Role of Foreign Assistance, 1972-1982, PhD Thesis, Berkeley 1984

Kurgat, Paul Kibiwott, Education as a Foreign Policy Tool: Kenyan Students' Airlifts to the Union of Soviet Socialist Republics and Eastern Europe, 1954-1991, PhD Thesis, Moi University 2013

Mac Con Uladh, Damian, Guests of the Socialist Nation? Foreign Students and Workers in the GDR, 1949-1990, PhD Thesis, London 2005

Maganga, Faustin Peter, Emerging Trends in Foreign-Aided Rural Development Programmes in Tanzania: The Case of Tanga Integrated Rural Development Programme (TIRDEP) and Rukwa Integrated Rural Development Programme (RUDEP), MA Thesis, Dar es Salaam 1990

Mnzava, Niwako E., The Contribution of Overseas Scholarships to the High-Level Manpower Requirements in Tanzania, MA Thesis, Dar es Salaam 1978

Ngasongwa, Juma, Evaluation of Externally Funded Regional Integrated Development Programmes (RIDEPs) in Tanzanina: Case Studies of Kigoma, Tanga and Iringa Regions, PhD Thesis, Norwich 1988

Nicholson, Timothy Alan, Teaching Tanzania: Education and the Creation of Tanzania in a Cold War World, PhD Dissertation, New York 2012

Obernhummer, Iris Christina, Experten der „wissenschaftlich-technischen Zusammenarbeit“ der DDR in Afrika. Alltag und Lebensweisen zwischen DDR-Richtlinien und angespannter Sicherheitslage in den 1970er und 1980er Jahren, Diplomarbeit, Wien 2010

Obernhummer, Iris Christina, Macht und Herrschaft des MfS in der DDR - wie eigenständig war das MfS? Analyse anhand der Bestätigung oder Ablehnung von Auslandskadern, Diplomarbeit, Wien 2011

Rabenschlag, Ann-Judith, Völkerfreundschaft nach Bedarf. Ausländische Arbeitskräfte in der Wahrnehmung von Staat und Bevölkerung der DDR, Dissertation, Stockholm 2014

Roberts, George, Politics, Decolonisation, and the Cold War in Dar es Salaam c. 1965-72, PhD Thesis, Warwick 2016

Roberts, George, Ostpolitik in Afrika: Tanzanian Politics, Non-Alignment, and the Inter-German Cold War, 1964-1972, Unveröffentlichtes Manuskript 2016 
Yoder, Traci L., „Is Use of Cosmetics Anti-Socialist?“ Gendered Consumption and the Fashioning of Urban Womanhood in Dar EsSalaam, Tanzania, 1975-1990, MA Thesis, Gainesville 2006

\section{B Veröffentlichte schriftliche Quellen und Literatur}

\section{B.1 Periodika: Nicht-wissenschaftliche Zeitschriften und Zeitungen}

Systematisch gesichtet wurden - z.T. durch lückenhafte Überlieferung beinträchtigt - die angegebenen Jahrgänge. Andere Jahrgänge bzw. Zeitschriften und Zeitungen ohne diese Angabe wurden nur bzgl. gezielter Fragestellungen und spezifischer Ereignisse konsultiert.

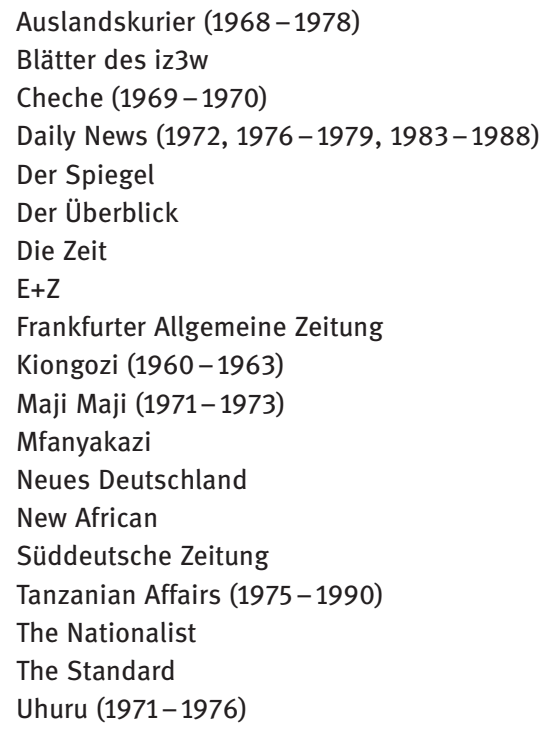

\section{B.2 Literatur}

Artikel aus oben (B.1) genannten Periodika werden hier nur angegeben, wenn sie in den Fußnoten mit Kurztitel aufgeführt werden.

Adi, Hakim, West Africans in Britain, 1900-1960. Nationalism, Pan-Africanism, and Communism, London 1998

Adi, Hakim, Pan-Africanism and Communism. The Communist International, Africa and the Diaspora, 1919-1939, Trenton, NJ 2013

Adichie, Chimamanda Ngozi, Americanah, London 2013 
Ahearne, Robert M., Development and Progress as Historical Phenomena in Tanzania:

„Maendeleo? We Had That in the Past“, in: African Studies Review 59/1 (2016), S. 77-96

Aich, Prodosh, Farbige unter Weißen, Köln 1962

Alexander, Jocelyn u. a., The Transnational Histories of Southern African Liberation Movements. An Introduction, in: Journal of Southern African Studies 43/1 (2017), S. 1-12

Allman, Jean, Phantoms of the Archive: Kwame Nkrumah, a Nazi Pilot Named Hanna, and the Contingencies of Postcolonial History-Writing, in: American Historical Review 118/1 (2013), S. $104-129$

Altbach, Philip G., Damned if You Do - Damned if You Don't: Counterparts, Neocolonialism, Dependency and the International Balance of Power, in: Irving J. Spitzberg, Hg., Exchange of Expertise: The Counterpart System in the New International Order, Boulder 1978, S. $65-80$

Altorfer-Ong, Alicia, They Came as Brothers, not Masters: Chinese Experts in Tanzania in the 1960s and 1970s, in: Journal für Entwicklungspolitik XXVI/3 (2010), S. 73-94

Aminzade, Ronald, Race, Nation, and Citizenship in Post-colonial Africa. The Case of Tanzania, Cambridge 2013

Ansprenger, Franz, Politische Geschichte Afrikas im 20. Jahrhundert, München 1992

Apthorpe, Raymond, Who Is International Aid? Some Personal Observations, in: Anne-Meike Fechter /Heather Hindman, Hg., Inside the Everyday Lives of Development Workers: The Challenges and Futures of Aidland, Boulder 2011, S. 193-210

Askew, Kelly M., Performing the Nation. Swahili Music and Cultural Politics in Tanzania, Chicago 2002

Augustine, Dolores L., Red Prometheus: Engineering and Dictatorship in East Germany, 1945-1990, Cambridge, Mass., 2007

Babu, A. M., Zanzibar and the Future, in: Haroub Othman, Hg., Babu: I Saw the Future and it Works. Essays Celebrating the Life of Comrade Abdulrahman Mohamed Babu, 1924-1996, Dar es Salaam 2001, S. 26-38

Babu, A. M., I Was the First Third World Minister to Recognise the GDR, in: Haroub Othman, Hg., Babu: I Saw the Future and it Works. Essays Celebrating the Life of Comrade Abdulrahman Mohamed Babu, 1924-1996, Dar es Salaam 2001, S. 48-58

Bahru Zewde, The Quest for Socialist Utopia. The Ethiopian Student Movement, c. 1960-1974, Woodbridge 2014

Bamba, Abou B., African Miracle, African Mirage. Transnational Politics and the Paradox of Modernization in Ivory Coast, Athens, Ohio 2016

Barkan, Joel D., An African Dilemma. University Students, Development and Politics in Ghana, Tanzania and Uganda, Nairobi 1975

Barker, Carol E. u.a., African Industrialisation. Technology and Change in Tanzania, Aldershot, Hants 1986

Bates, Robert H., Markets and States in Tropical Africa: The Political Basis of Agricultural Policies; Berkeley 1981

Bayart, Jean-François, Africa in the World: A History of Extraversion, in: African Affairs 99/395 (2000), S. $217-267$

Beblo, Lothar u.a., Bei Allah! Das ist doch eine Ungerechtigkeit! Mitarbeiter erinnern sich, in: Willi Erl, Hg., Betrifft: Zusammenarbeit: 25 Jahre Deutscher Entwicklungsdienst, Berlin 1988, S. $45-50$ 
Becher, Jürgen, Dar es Salaam, Tanga und Tabora. Stadtentwicklung in Tansania unter deutscher Kolonialherrschaft (1885-1914), Stuttgart 1997

Beckmann, Gabriele, Partizipation in der Entwicklungszusammenarbeit. Mode, Methode oder politische Vision?, Hamburg 1997

Bendera, Stella, Moving Beyond Issues of Access and Equity in Promoting Education for Girls in Tanzania, in: Christine Heward/Sheila Bunwaree, Hg., Gender, Education and Development: Beyond Access to Empowerment, London 1999, S. 117-132

Bendix, Daniel, Resistance or Damp Squibs? Challenges to Colonial Power in Contemporary German Development Interventions in the Area of Reproductive Health in Tanzania, in: Journal für Entwicklungspolitik XXX/1 (2014), S. 21-43

Benger, Franziska, Die Entwicklungszusammenarbeit der DDR in Sansibar/Tansania, in: Ulrich van der Heyden/Franziska Benger, Hg., Kalter Krieg in Ostafrika: Die Beziehungen der DDR zu Sansibar und Tansania, Berlin 2009, S. 341-389

Bernal, Victoria, Colonial Moral Economy and the Discipline of Development: The Gezira Scheme and „Modern“ Sudan, in: Cultural Anthropology 12/4 (1997), S. 447-449

Bichmann, Wolfgang u.a., „Westliche“ Medizin in Ländern der Dritten Welt. Am Beispiel Tansania: Ein Trojanisches Pferd des Neo-Kolonialismus, in: Wolfgang Fritz, Hg., Jahrbuch für kritische Medizin: Band 2, Hamburg 1977, S. 170-192

Bienen, Henry, Tanzania: Party Transformation and Economic Development, Expanded Edition, Princeton 1970

Bienefeld, Manfred A., Planning People, in: J. F. Rweyemamu u. a., Hg., Towards Socialist Planning, Dar es Salaam 1972, S. 166-199

Bierschenk, Thomas / Georg Elwert, Hg., Entwicklungshilfe und ihre Folgen: Ergebnisse empirischer Untersuchungen in Afrika, Frankfurt/Main, New York 1993

Bierschenk, Thomas /Jean-Pierre Olivier de Sardan, Studying the Dynamics of African Bureaucracies. An Introduction to States at Work, in: dies., Hg., States at Work: Dynamics of African Bureaucracies, Leiden, Boston 2014, S. 3-34

Bierschenk, Thomas, u.a., Local Development Brokers in Africa. The Rise of a New Social Category. Arbeitspapier Nr. 13, Mainz 2002

Bierschenk, Thomas, Development Projects as Arenas of Negotiation for Strategic Groups: A Case Study from Bénin, in: Sociologia Ruralis 28/2-3 (1988), S. 146-160

Birmingham, David, The Decolonization of Africa, London 1995

Bizimana, Nsekuye, White Paradise, Hell for Africa?, Berlin 1989

Bjerk, Paul, Sovereignty and Socialism in Tanzania: The Historiography of an African State, in: History in Africa 37 (2010), S. 275-319

Bjerk, Paul, Building a Peaceful Nation. Julius Nyerere and the Establishment of Sovereignty in Tanzania, 1960-1964, Woodbridge 2015

Bjerk, Paul, Julius Nyerere, Athens 2017

Bley, Helmut /Rolf Hofmeier: Director of the Institute of African Affairs, 1976-2000. A retrospective., in: Ulf Engel u.a., Hg., Tanzania Revisited: Political Stability, Aid Dependency, and Development Constraints, Hamburg 2000, S. ix-xii

Bohnet, Michael, Development Policy in Sub-Saharan Africa and the Case of Tanzania, in: Ulf Engel u.a., Hg., Tanzania Revisited: Political Stability, Aid Dependency, and Development Constraints, Hamburg 2000, S. 3-16

Bohnet, Michael, Geschichte der deutschen Entwicklungspolitik. Strategien, Inhalte, Zeitzeugen, Herausforderungen, Konstanz 2015 
Bols, Manfred, Ende der Schweigepflicht. Aus dem Leben eines Geheimdienstlers, Berlin 2002 Boltovskaja, Svetlana, Bildungsmigranten aus dem subsaharischen Afrika in Moskau und St. Petersburg. Selbst- und Fremdbilder, Herbolzheim 2014

Bourdieu, Pierre /Loïc J. D. Wacquant, An Invitation to Reflexive Sociology, Cambridge 1992

Bourdieu, Pierre, Die biographische Illusion, in: BIOS 3/1 (1990), S. $75-81$

Bourdieu, Pierre, Das Elend der Welt. Zeugnisse und Diagnosen alltäglichen Leidens an der Gesellschaft, Konstanz 1997

Bourdieu, Pierre, Praktische Vernunft. Zur Theorie des Handelns, Frankfurt am Main 1998

Brähler, Rainer, Entwicklungspolitik und Bildungshilfe. Geschichte, Funktion, Legitimation, Frankfurt am Main 1986

Brahm, Felix /Adam Jones, Afrikanistik, in: Ulrich von Hehl/Uwe John/Manfred Rudersdorf, Geschichte der Universität Leipzig 1409-2009, Leipzig 2009, S. 295-324

Brazinsky, Gregg A., Winning the Third World: Sino-American Rivalry during the Cold War, Chapel Hill 2017

Brennan, James /Andrew Burton, The Emerging Metropolis: A History of Dar es Salaam circa $1862-2000$, in: James R. Brennan u.a., Hg., Dar es Salaam: Histories from an Emerging African Metropolis, Dar es Salaam 2007, S. 13-75

Brennan, James R., Youth, the TANU Youth League and Managed Vigilantism in Dar es Salaam, Tanzania, 1925-73, in: Africa 76/2 (2006), S. 221-246

Brennan, James R., Taifa. Making Nation and Race in Urban Tanzania. Athens 2012

Brennan, James R., Julius Rex. Nyerere through the Eyes of His Critics, 1953-2013, in: Journal of Eastern African Studies 8/3 (2014), S. 459-477

Brock, Angela, Producing the „Socialist Personality“? Socialisation, Education, and the Emergence of New Patterns of Behaviour, in: Mary Fulbrook, Hg., Power and Society in the GDR, 1961-1979: The „Normalisation of rule“?, New York 2009, S. 220-252

Bryceson, Deborah, Food Insecurity and the Social Division of Labour in Tanzania 1919-85, London 1990

Buchert, Lene, Education in the Development of Tanzania, 1919-90, London u. a. 1994

Bücking, Hans-Jörg, Hg., Entwicklungspolitische Zusammenarbeit in der Bundesrepublik Deutschland und der DDR, Berlin 1998

Burgess, G. Thomas, Cinema, Bell Bottoms, and Miniskirts: Struggles over Youth and Citizenship in Revolutionary Zanzibar, in: International Journal of African Historical Studies 35/2-3 (2002), S. 287-313

Burgess, G. Thomas, A Socialist Diaspora: Ali Sultan Issa, the Soviet Union and the Zanzibari Revolution, in: Maxim Matusevich, Hg., Africa in Russia, Russia in Africa: Three Centuries of Encounters, Trenton, NJ 2007, S. 263-291

Burgess, G. Thomas, Race, Revolution, and the Struggle for Human Rights in Zanzibar. The Memoirs of Ali Sultan Issa and Seif Sharif Hamad, Athens 2009

Burgess, G. Thomas, To Differentiate Rice from Grass. Youth Labor Camps in Revolutionary Zanzibar, in: Andrew Burton/Hélène Charton-Bigot, Hg., Generations Past: Youth in East African History, Athens 2010, S. 221-236

Burton, Andrew, African Underclass. Urbanisation, Crime \& Colonial Order in Dar es Salaam, London 2005

Burton, Eric, ,....What Tribe Should We Call Him?“ The Indian Diaspora, the State and the Nation in Tanzania since ca. 1850, in: Stichproben. Wiener Zeitschrift für kritische Afrikastudien 13/25 (2013), S. 1- 28 
Burton, Eric, Review Article: Sovereignty, Socialism and Development in Postcolonial Tanzania, in: Stichproben. Wiener Zeitschrift für kritische Afrikastudien 16/31 (2016), S. 109-126

Burton, Eric, Introduction. Journeys of Education and Struggle: African Mobility in Times of Decolonization and the Cold War, in: Stichproben. Wiener Zeitschrift für kritische Afrikastudien 18/34 (2018), S. 1-17

Burton, Eric, Solidarität und ihre Grenzen. Die „Brigaden der Freundschaft“ der DDR, in Frank Bösch/Caroline Moine/Stefanie Senger, Hg., Internationale Solidarität: Globales Engagement in der Bundesrepublik und der DDR, Göttingen 2018, S. 152-185

Burton, Eric, Navigating Global Socialism: Tanzanian Students in and Beyond East Germany, in: Cold War History 19/1 (2019), S. 63-83

Burton, Eric, Hubs of Decolonization. African Liberation Movements and Eastern Connections in Cairo, Accra and Dar es Salaam, in: Lena Dallywater/Helder A. Fonseca/Chris Saunders, Hg., Southern African Liberation Movements and the Global Cold War „East“: Transnational Activism 1960-1990, Berlin 2019, S. 25-56

Burton, Eric, Decolonisation, the Cold War and Africans' Routes to Higher Education Overseas, 1957-1965, in: Journal of Global History 15/1 (2020), S. 169-191

Büschel, Hubertus /Daniel Speich, Einleitung - Konjunkturen, Probleme und Perspektiven der Globalgeschichte von Entwicklungszusammenarbeit, in: Hubertus Büschel/Daniel Speich, Hg., Entwicklungswelten: Globalgeschichte der Entwicklungszusammenarbeit, Frankfurt am Main 2009, S. 7-29

Burton, Eric, Einführung: Entwicklungsarbeit und globale Modernisierungsexpertise 41/4 (2015), S. 535-551

Büschel, Hubertus, In Afrika helfen. Akteure westdeutscher „Entwicklungshilfe“ und ostdeutscher „Solidarität“ 1955-1975, in: Anja Kruke, Hg., Dekolonisation: Prozesse und Verflechtungen 1945-1990, Bonn 2009, S. 333-365

Büschel, Hubertus, Hilfe zur Selbsthilfe. Deutsche Entwicklungsarbeit in Afrika 1960-1975, Frankfurt am Main 2014

Butler, L. J. /Sarah Stockwell, Hg., The Wind of Change, London 2013

Butters, Hannelore, Zur wirtschaftlichen Zusammenarbeit der DDR mit Mosambik, in: Matthias Voß, Hg., Wir haben Spuren hinterlassen!: Die DDR in Mosambik Erlebnisse, Erfahrungen und Erkenntnisse aus drei Jahrzehnten, Münster 2005, S. 199-215

Byrne, Jeffrey James, Mecca of Revolution. Algeria, Decolonization, and the Third World Order, New York 2016

Callaci, Emily, Street Archives and City Life, Durham, London 2017

Calori, Anna u.a., Hg., Between East and South. Spaces of Interaction in the Globalizing Economy of the Cold War, Berlin/Boston 2019

Cassam, Annar /Chambi Chachage, Hg., Africa's Liberation. The Legacy of Nyerere, Nairobi 2010

Chachage, Chachage Seithy L., Environment, Aid and Politics in Zanzibar, Dar es Salaam 2000

Charlés, Laurie L., Intimate Colonialism. Head, Heart, and Body in West African Development Work, Walnut Creek, CA 2007

Claus, Burghard / Hans-Helmut Taake, Die Entwicklungspolitik der DDR - Ein Rückblick, in: Ulrich van der Heyden u. a., Hg., Die DDR und Afrika: Zwischen Klassenkampf und neuem Denken, Münster 1993, S. 245-259

Cobbs Hoffman, Elizabeth, All You Need is Love. The Peace Corps and the Spirit of the 1960s, Cambridge, Mass. 1998 
Cohen, Erik, Expatriate Communities, in: Current Sociology 24/3 (1977), S. 5-90

Coles, Anne /Anne-Meike Fechter, Hg., Gender and family among transnational professionals, New York 2008

Conrad, Sebastian /Shalini Randeria, Hg., Jenseits des Eurozentrismus. Postkoloniale Perspektiven in den Geschichts- und Kulturwissenschaften, Frankfurt 2002

Conrad, Sebastian, Globalgeschichte. Eine Einführung, München 2013

Cooke, Bill /Uma Kothari, Hg., Participation: the New Tyranny?, London, New York 2001

Cooper, Frederick, Africa since 1940. The Past of the Present, Cambridge 2002

Cooper, Frederick, Writing the History of Development, in: Journal of Modern European History 8/1 (2010), S. 5-23

Cooper, Frederick, Africa in the World. Capitalism, Empire, Nation-State, Cambridge, Massachusetts 2014

Coulson, Andrew, Tanzania's Fertilizer Factory, in: Andrew Coulson, Hg., African Socialism in Practice. The Tanzanian Experience, Nottingham 1979, S. 184-190

Coulson, Andrew, Tanzania. A political economy, Second edition, Oxford 2013, S. 354-356

Cowen, Michael P. /Robert W. Shenton, Doctrines of development, London 1996

Crehan, Kate /Achim von Oppen, „Understandings of Development“: An Arena of Struggle: The Story of a Development Project in Zambia, in: Sociologia Ruralis 28/2-3 (1988),

S. $113-145$

DAAD, 40 Years Supporting Excellence. DAAD Regional Office for Africa, Bonn 2014

Danckwortt, Dieter, Die Anfänge der Entwicklungspolitik in der Bundesrepublik Deutschland in den fünfziger Jahren und die Weichenstellungen für die folgenden Jahrzehnte - Ursache und Wirkung, in: Manfred Glagow, Hg., Deutsche und internationale Entwicklungspolitik: Zur Rolle staatlicher, supranationaler und nicht-regierungsabhängiger Organisationen im Entwicklungsprozeß der Dritten Welt, Opladen 1990, S. 13-17

Delehanty, Sean, From Modernization to Villagization: The World Bank and Ujamaa, in: Diplomatic History 44/2 (2020), S. 289-314

Dietrich, Anne, Zwischen solidarischem Handel und ungleichem Tausch. Zum Südhandel der DDR am Beispiel des Imports kubanischen Zuckers und äthiopischen Kaffees, in: Journal für Entwicklungspolitik 30/3 (2014), S. $48-67$

Dietrich, Anne, Kaffee in der DDR - „Ein Politikum ersten Ranges“, in: Christiane Berth u.a., Hg., Kaffeewelten: Historische Perspektiven auf eine globale Ware im 20. Jahrhundert, Göttingen 2015, S. 225-248

Djagalov, Rossen /Christine Evans, Moskau 1960: Wie man sich eine sowjetische Freundschaft mit der Dritten Welt vorstellte, in: Andreas Hilger, Hg., Die Sowjetunion und die Dritte Welt: UdSSR, Staatssozialismus und Antikolonialismus im Kalten Krieg 1945-1991, München 2009, S. 83-105

Doering-Manteuffel, Anselm, Die Bundesrepublik Deutschland in der Ära Adenauer, Darmstadt 1988

Döring, Hans-Joachim, Es geht um unsere Existenz. Die Politik der DDR gegenüber der Dritten Welt am Beispiel von Mosambik und Äthiopien, Berlin 1999

Dorsch, Hauke, Red or Black Atlantic? Mozambican Students in Cuba and Their Re-Integration at Home, in: Zeitschrift für Ethnologie 136/2 (2011), S. 65-86

Dorsch, Hauke, Trans-Atlantic Educational Crossroads: Experiences of Mozambican Students in Cuba, in: Ingrid Kummels u. a., Hg., Transatlantic Caribbean. Dialogues of People, Practices, Ideas, Bielefeld, Berlin 2014, S. 77-96 
Dufner, Georg J., Chile als Partner, Exempel und Prüfstein, in: Vierteljahreshefte für Zeitgeschichte 61/4 (2013), S. 513-548

Dvorácek, Jan u.a., A History of Czechoslovak Involvement in Africa. Studies From the Colonial Through the Soviet Eras, Lewiston, NY 2014

Dyck, Noel, Anthropological Perspectives on Discipline: An Introduction to the Issues, in: Noel Dyck, Hg., Exploring Regimes of Discipline: The Dynamics of Restraint, New York, Oxford 2008, S. 1-22

Eckert, Andreas, Herrschen und Verwalten. Afrikanische Bürokraten, staatliche Ordnung und Politik in Tanzania, 1920-1970, München 2007

Eckert, Andreas, „We Are All Planners Now.“ Planung und Dekolonisation in Afrika, in: Geschichte und Gesellschaft 34/3 (2008), S. 375-397

Eckert, Andreas, „We Must Run While Others Walk“: African Civil Servants, State Ideologies and Bureaucratic Practices in Tanzania, from the 1950s to the 1970s, in: Thomas Bierschenk/Olivier de Sardan, Jean-Pierre, Hg., States at Work: Dynamics of African Bureaucracies, Leiden 2014, S. 205-219

Eckert, Andreas, Westdeutsche Entwicklungszusammenarbeit mit Afrika. Ein Blick auf die 1950er bis 1970er Jahre, in: Alexander Gallus u.a., Hg., Deutsche Zeitgeschichte transnational, Göttingen 2015, S. 25-42

Edwards, Sebastian, Toxic Aid. Economic Collapse and Recovery in Tanzania, Oxford 2014

Elmer, Sara, u.a., Hg., Handlungsfeld Entwicklung. Schweizer Erwartungen und Erfahrungen in der Geschichte der Entwicklungsarbeit, Basel 2014

Elshorst, Hansjörg, Organisation und Entwicklung - Zum System der deutschen Entwicklungspolitik, in: Manfred Glagow, Hg., Deutsche und internationale Entwicklungspolitik: Zur Rolle staatlicher, supranationaler und nichtregierungsabhängiger Organisationen im Entwicklungsprozeß der Dritten Welt, Opladen 1990 , S. $19-34$

Elwert-Kretschmer, Karola /Georg Elwert, Mit den Augen der Béniner. Eine Evaluation von 25 Jahren ded in Bénin, in: Africa Spectrum 26/3 (1990), S. 335-350

Emery, David A., From Kansas to Kilimanjaro: A Memoir of a Family That Survived Two World Wars and Outwitted Russian Espionage, Bloomington 2012

Engel, Ulf / Hans-Georg Schleicher, Thesen zur Afrikapolitik der beiden deutschen Staaten. Mit Kommentaren aus der politischen Praxis von Volkmar Köhler und Helmut Matthes, Hamburg 1997

Engel, Ulf / Hans-Georg Schleicher, Die beiden deutschen Staaten in Afrika. Zwischen Konkurrenz und Koexistenz, 1949-1990, Hamburg 1998

Engel, Ulf, „I Will Not Recognise East Germany Just Because Bonn Is Stupid“:

Anerkennungsdiplomatie in Tansania, 1964 bis 1965, in: Ulrich van der Heyden/Franziska Benger, Hg., Kalter Krieg in Ostafrika: Die Beziehungen der DDR zu Sansibar und Tansania, Berlin 2009, S. 9-30

Engel, Ulf, Die Afrikapolitik der Bundesrepublik Deutschland 1949-1999. Rollen und Identitäten, Hamburg 2000

Engerman, David C., The Second World's Third World, in: Kritika: Explorations in Russian and Eurasian History 12/1 (2011), S. 183-211

Engerman, David C., Development Politics and the Cold War, in: Diplomatic History 41/1 (2017), S. $1-19$ 
Engerman, David C., The Price of Aid. The Economic Cold War in India. Cambridge, Massachusetts 2018

Erel, Umut, Migrating Cultural Capital: Bourdieu in Migration Studies, in: Sociology 44/4 (2010), S. 642-660

Erl, Willi, Hg., Mit anderen Augen. Entwicklungshelfer sehen die Dritte Welt, Berlin 1989

Erler, Brigitte, Tödliche Hilfe. Bericht von meiner letzten Dienstreise in Sachen Entwicklungshilfe, Freiburg 1985

Eriksson Baaz, Maria, The Paternalism of Partnership. A Postcolonial Reading of Identity in Development Aid, New York 2005

Escobar, Arturo, Encountering Development. The Making and Unmaking of the Third World, Princeton, N. J. 1995

Eugster, Carola, Soldatische Mobilität im „Kalten Krieg“. Deutsche Ausbildungshilfe für afrikanische Soldaten in Afrika und in der Bundesrepublik in den 1960er Jahren, in: Christoph Rass, Hg., Militärische Migration vom Altertum bis zur Gegenwart, Paderborn 2016, S. $165-188$

Evers, Hans-Dieter /Tilman Schiel, Strategische Gruppen. Vergleichende Studien zu Staat, Bürokratie und Klassenbildung in der Dritten Welt, Berlin 1988

Evers, Hans-Dieter, Die Theorie strategischer Gruppen, in: Manfred Schulz, Hg., Entwicklung: Die Perspektive der Entwicklungssoziologie, Wiesbaden 1997, S. 155-160

Evers, Hans-Dieter, Wissen ist Macht: Experten als Strategische Gruppe. ZEF Working Paper Series, Bonn 2005

Fana Gebresenbet, Securitisation of Development in Ethiopia. The Discourse and Politics of Developmentalism, in: Review of African Political Economy 41/sup1 (2015), S. S64-S74

Faist, Thomas, Migrants as Transnational Development Agents: An Inquiry into the Newest Round of the Migration-Development Nexus, in: Population, Space and Place, 14/1 (2008), S. 21- 42

Fechter, Anne-Meike, Anybody at Home? The Inhabitants of Aidland, in: Anne-Meike Fechter/ Heather Hindman, Hg., Inside the Everyday Lives of Development Workers: The Challenges and Futures of Aidland, Boulder 2011, S. 131-149

Feierman, Steven, Peasant Intellectuals. Anthropology and History in Tanzania, Madison, Wisconsin 1990

Ferguson, James, The Anti-Politics Machine. „Development,“ Depoliticization, and Bureaucratic Power in Lesotho, Minneapolis 1994

Filatova, Irina, Indoctrination or Scholarship? Education of Africans at the Communist University of the Toilers of the East in the Soviet Union, 1923-1937, in: Paedagogica Historica 35/1 (1999), S. 41-66

Fischer, Gundula, Unsere Fabrik - unsere Familie: Vorstellungen von Verwandtschaft und Familie in einem tansanischen Industriebetrieb vor der Privatisierung und danach, Berlin 2006

Fischer, Karin u.a., Hg., Handbuch Entwicklungsforschung, Wiesbaden 2016

Fitschen, Klaus, Wissenschaft im Dienste des Sozialismus. Die Universität Leipzig vom Mauerbau bis zur Friedlichen Revolution 1961-1989, in: Ulrich von Hehl u.a., Hg., Geschichte der Universität Leipzig 1409-2009: Band 3: Das zwanzigste Jahrhundert 1909-2009. 2010, S. 570-777

Fleer, Peter, „Entangling Archives“. Die Bestände des Schweizerischen Bundesarchivs zwischen Entwicklungsdiskurs und historischer Reflexion, in: Sara Elmer u.a., Hg., 
Handlungsfeld Entwicklung. Schweizer Erwartungen und Erfahrungen in der Geschichte der Entwicklungsarbeit, Basel 2014, S. 281-308

Fouéré, Marie-Aude, Recasting Julius Nyerere in Zanzibar: The Revolution, the Union and the Enemy of the Nation, in: dies., Hg., Remembering Julius Nyerere in Tanzania: History, Memory, Legacy, Dar es Salaam 2015, S. 171-196

Fouéré, Marie-Aude, Hg., Remembering Julius Nyerere in Tanzania. History, Memory, Legacy, Dar es Salaam 2015

Frey, Marc, u.a., Hg., International Organizations and Development. 1945-1990, Basingstoke u. a. 2014

Frey, Marc, Entwicklungspolitik, in: Jost Dülffer/Wilfried Loth, Hg., Dimensionen internationaler Geschichte, München 2012, S. 293-312

Friedman, Jeremy Scott, Shadow Cold War. The Sino-Soviet Competition for the Third World, Chapel Hill 2015

Fröhlich, Birgit, Gedanken zur Entwicklungszusammenarbeit der DDR mit Afrika, in: Ulrich van der Heyden u.a., Hg., Die DDR und Afrika: Zwischen Klassenkampf und neuem Denken, Münster 1993, S. 148-164

Froschauer, Ulrike /Manfred Lueger, Das qualitative Interview. Zur Praxis interpretativer Analyse sozialer Systeme, Wien 2003, S. 36-40

Fuchs-Heinritz, Werner /Alexandra König, Pierre Bourdieu. Eine Einführung, 3., überarb. Aufl., Konstanz 2014

Fulbrook, Mary, The People's State. East German Society from Hitler to Honecker, New Haven 2005

Galabawa, Justinian C.J., Funding, Selected Issues and Trends in Tanzania Higher Education, in: Higher Education 21 (1991), S. 49-61

Ghai, Dharam P. /Yash P. Ghai, Asians in Tanzania, in: Knud Erik Svendsen/Merete Teisen, Hg., Self Reliant Tanzania, Dar es Salaam 1969, S. 90-110

Giblin, James L., A History of the Excluded. Making Family a Refuge from State in TwentiethCentury Tanzania, Oxford 2005

Gilman, Nils, Mandarins of the Future. Modernization Theory in Cold War America, Baltimore 2007

Gilman, Nils, H-Diplo Article Review No. 238-B. Special Forum: Modernization as a Global Project, Diplomatic History 23/3 (2009), in: H-Diplo.

Glagow, Manfred u.a., Die deutschen Entwicklungsbanken. Zur Organisation und Tätigkeit der Kreditanstalt für Wiederaufbau (KfW) und der Deutschen Finanzierungsgesellschaft für Beteiligungen in Entwicklungsländern (DEG), Saarbücken 1985

Glagow, Manfred u.a., Das Bundesministerium für wirtschaftliche Zusammenarbeit (BMZ). Entstehungszusammenhang, Personalpolitik, Steuerungsfähigkeit, Pfaffenweiler 1989

Gläser, Jochen / Grit Laudel, Experteninterviews und qualitative Inhaltsanalyse. Als Instrumente rekonstruierender Untersuchungen, 4. Aufl, Wiesbaden 2010, S. 12-16

Glassman, Jonathon, War of Words, War of Stones. Racial Thought and Violence in Colonial Zanzibar, Bloomington 2011

Gleijeses, Piero, Conflicting Missions. Havana, Washington, and Africa, 1959-1976, Chapel Hill 2002

Gleijeses, Piero, Moscow's Proxy? Cuba and Africa 1975-1988, in: Journal of Cold War Studies 8/2 (2006), S. 3-51 
Globerson, Arye, Interaction between Foreign Assistance Personnel and Local Counterparts, in: Irving J. Spitzberg, Hg., Exchange of Expertise: The Counterpart System in the New International Order, Boulder 1978, S. 159-179

Go, Julian, Global Fields and Imperial Forms: Field Theory and the British and American Empires, in: Sociological Theory 26/3 (2008), S. 201-229

Goerg, Odile /Françoise Raison-Jourde, Hg., Les coopérants français en Afrique: Portrait de groupe (années 1950-1990), Paris 2012

Gorski, Philip S., Hg., Bourdieu and Historical Analysis. Politics, History, and Culture, Durham, NC 2013

Grandner, Margarete /Arno Sonderegger, Hg., Nord-Süd-Ost-West Beziehungen. Eine Einführung in die Globalgeschichte, Wien 2015

Gray, Clive S., Hg., Inside Independent Nigeria. Diaries of Wolfgang Stolper, 1960-1962, Aldershot, Burlington 2003

Gray, William Glenn, Germany's Cold War. The Global Campaign to Isolate East Germany, 1949-1969, Chapel Hill 2003

Green, Maia, The Development State. Aid, Culture and Civil Society in Tanzania, Woodbridge, Suffolk 2014

Green, Reginald H., Tanzanian Political Economy Goals, Strategies, and Results, 1967-1974: Notes Towards an Interim Assessment, in: Bismarck U. Mwansasu/Cranford Pratt, Hg., Towards Socialism in Tanzania, Dar es Salaam 1979, S. 15-41

Gross, Bernd u.a., Akademiker aus Entwicklungsländern in der Bundesrepublik Deutschland. Zwischen Brain Drain und Rückkehr: eine Studie im Auftrag des Centrums für internationale Migration und Entwicklung, Saarbrücken 1982

Grosskopf, Sabine, Kulturschock und Fremdverhaltensunterricht. Ausländische Studenten in der BRD, Hamburg 1982

Guimont, Fabienne, Les étudiants africains en France, 1950-1965, Paris 1997

GTZ, University of Dar es Salaam Faculty of Engineering, Eschborn 1979

Haase, Ingo, Handlungsspielräume einer quasi-staatlichen Entwicklungshilfe-Organisation. Der Deutsche Entwicklungsdienst, Münster 1991

Haase, Ingo, Zwischen Lenkung und Selbstbestimmung. Geschichte und Gegenwart des Deutschen Entwicklungsdienstes, Berlin 1996

Hacker, Hanna, Queer entwickeln. Feministische und postkoloniale Analysen, Wien 2012

Hall, Stuart, Rassismus als ideologischer Diskurs, in: Das Argument 31/178 (1989), S. 913-921

Hancock, Graham, Lords of Poverty. The Power, Prestige, and Corruption of the International Aid Business, Boston 1989

Harisch, Immanuel R., Facets of Walter Rodney's Pan-African Intellectual Activism during his Dar es Salaam Years, in: Stichproben. Wiener Zeitschrift für kritische Afrikastudien 20/38 (2020), S. 101-129

Harrison, Elizabeth, Beyond the Looking Glass? „Aidland“ Reconsidered, in: Critique of Anthropology 33/3 (2013), S. 263-279

Hartmann, Jeanette, The Arusha Declaration Revisited, in: African Review 12 (1985), S. 1-11

Hausberger, Bernd, Globalgeschichte als Lebensgeschichte(n), in: Bernd Hausberger, Hg., Globale Lebensläufe: Menschen als Akteure des weltgeschichtlichen Geschehens, Wien 2006, S. 9-27

Hatzky, Christine Kubaner in Angola. Süd-Süd-Kooperation und Bildungstransfer 1976-1991, München 2012 
Havnevik, Kjell J., Tanzania: The Limits to Development from Above, Uppsala 1993

Heckmann, Friedrich, Entwicklungsdienst: Hilfe für die „Unterprivilegierten“? Subjektive und objektive Momente der Tätigkeit von Entwicklungshelfern, in: Gerhard Wurzbacher, Hg., Störfaktoren der Entwicklungspolitik, Stuttgart 1975, S. 15-35

Heimann, Christian, Systembedingte Ursachen des Niedergangs der DDR-Wirtschaft. Das Beispiel der Textil- und Bekleidungsindustrie 1945-1989, Frankfurt am Main 1997

Hein, Bastian, Die Westdeutschen und die Dritte Welt. Entwicklungspolitik und Entwicklungsdienste zwischen Reform und Revolte 1959-1974, München 2006

Heinemann, Manfred, Fakten und Zahlen zum DAAD. Personen, Programme und Projekte - ein Rundblick, 4. Aufl., Band 2, Bonn 2000

Helleiner, Eric, Forgotten Foundations of Bretton Woods. International Development and the Making of the Postwar Order, Ithaca, London 2014

Helm, Christian, Botschafter der Revolution. Das transnationale Kommunikationsnetzwerk zwischen der Frente Sandinista de Liberación Nacional und der bundesdeutschen Nicaragua-Solidarität 1977-1990, Berlin 2018

Heron, Barbara, Desire for Development. Whiteness, Gender, and the Helping Imperative, Waterloo 2007

Hewitt, Tom/David Wield, Tanzanian Networks. Networks in Tanzanian Industrialisation, in: Science and Public Policy 24/6 (1997), S. 395-404

Hindman, Heather /Anne-Meike Fechter, Introduction, in: Anne-Meike Fechter/Heather Hindman, Hg., Inside the Everyday Lives of Development Workers: The Challenges and Futures of Aidland, Boulder 2011

Hirji, Karim F., Cheche: Reminiscences of a Radical Magazine 2010

Hirji, Karim F., Tribulations of an Independent Magazine, in: Karim F. Hirji, Hg., Cheche: Reminiscences of a Radical Magazine 2010, S. 35-51

Hirji, Karim F., Not So Silent A Spark, in: Karim F. Hirji, Hg., Cheche: Reminiscences of a Radical Magazine, Dar es Salaam 2010, S. 53-63

Hirji, Karim F., Growing up with Tanzania. Memories, Musings and Maths, Oxford 2014 Hirschinger, Frank, Der Spionage verdächtig. Asylanten und ausländische Studenten in Sachsen-Anhalt 1945-1970, Göttingen 2009

Hirschman, Albert O., Development Projects Observed, Washington, D.C 1995

Hodge, Joseph Morgan u.a., Hg., Developing Africa. Concepts and Practices in TwentiethCentury Colonialism, Manchester 2014

Hodge, Joseph Morgan/Gerald Hödl, Introduction, in: Joseph Morgan Hodge u.a., Hg., Developing Africa: Concepts and Practices in Twentieth-Century Colonialism, Manchester 2014, S. $1-34$

Hodge, Joseph Morgan, Triumph of the Expert. Agrarian Doctrines of Development and the Legacies of British Colonialism, Athens 2007

Hodge, Joseph Morgan, British Colonial Expertise, Post-Colonial Careering and the Early History of International Development, in: Journal of Modern European History 8/1 (2010), S. $24-46$

Hodge, Joseph Morgan, Colonial Experts, Developmental and Environmental Doctrines, and the Legacies of Late British Colonialism, in: Christina Folke Ax u.a., Hg., Cultivating the Colonies: Colonial states and their Environmental Legacies, Athens 2011, S. 300-325

Hodge, Joseph Morgan, Writing the History of Development (Part 1: The First Wave), in: Humanity $6 / 3$ (2015), S. $429-463$ 
Hodge, Joseph Morgan, Writing the History of Development (Part 2: Longer, Deeper, Wider), in: Humanity $7 / 1$ (2016), S. 125-174

Hofmeier, Rolf, Möglichkeiten und Grenzen deutscher Entwicklungspolitik gegenüber Afrika, in: Helmut Bley/Rainer Tetzlaff, Afrika und Bonn: Versäumnisse und Zwänge deutscher Afrika-Politik, Reinbek bei Hamburg 1978, S. 192-253

Hofmeier, Rolf, Die Tanga-Region - Regionaler Schwerpunkt der deutschen Entwicklungshilfeprogramme in Tansania, in: Werner Pfennig u.a., Hg., Entwicklungsmodell Tansania, Sozialismus in Afrika: Geschichte, Ökonomie, Politik, Erziehung, Frankfurt/Main, New York 1980, S. 310-339

Hofmeier, Rolf, Aid from the Federal Republic of Germany to Africa, in: The Journal of Modern African Studies 24/4 (1986), S. 577-601

Hong, Young-Sun, Cold War Germany, the Third World, and the Global Humanitarian Regime, New York 2015

Howell, Jude, The End of an Era: The Rise and Fall of G.D.R. Aid, in: Journal of Modern African Studies 32/2 (1994), S. 305-328

Hübner, Peter, Antielitäre Eliten?, in: ders., Hg., Eliten im Sozialismus: Beiträge zur Sozialgeschichte der DDR, Köln 1999, S. 9-36

Hunter, Emma, Political Thought and the Public Sphere in Tanzania. Freedom, Democracy, and Citizenship in the Era of Decolonization, New York 2015

Husemann, Bettina /Annette Neumann, DDR-VR Angola: Fakten und Zusammenhänge zur bildungspolitischen Zusammenarbeit von 1975 bis 1989, in: Heyden, Ulrich van der u.a., Hg., Engagiert für Afrika: Die DDR und Afrika II, Münster 1994, S. 158-178

Hüsken, Thomas, Der Stamm der Experten. Rhetorik und Praxis des Interkulturellen Managements in der deutschen staatlichen Entwicklungszusammenarbeit, Bielefeld 2006

Hydén, Göran, Beyond Ujamaa in Tanzania. Underdevelopment and an Uncaptured Peasantry, London 1980

Iandolo, Alessandro, The Rise and Fall of the „Soviet Model of Development“ in West Africa, 1957-64, in: Cold War History 12/4 (2012), S. 683-704

Iliffe, John, A Modern History of Tanganyika, Cambridge 1979

Iliffe, John, East African Doctors. A History of the Modern Profession, Cambridge, New York 1998

Illi, Holger, Development Experts at the Interface: An Inquiry into the Knowledge Dimension of Allocative and Strategic Action in the Arena of a German/Nepalese Health Development Project, Research Report, Bielefeld 2001

Ishemo, Shubi L., „A Symbol That Cannot be Substituted“: The Role of Mwalimu J K Nyerere in the Liberation of Southern Africa, 1955-1990, in: Review of African Political Economy 27/ 83 (2000), S. $81-94$

Itandala, Buluda, University of Dar es Salaam's Immediate Response to Musoma Resolution, in: Isaria N. Kimambo u.a., Hg., In Search of Relevance: A History of the University of Dar es Salaam, Dar es Salaam 2008, S. 193-205

Ivaska, Andrew M., Cultured States. Youth, Gender, and Modern Style in 1960s Dar es Salaam, Durham 2011

Ivaska, Andrew M., Of Students, „Nizers“, and a Struggle over Youth. Tanzania’s 1966 National Service Crisis, in: Africa Today 51/3 (2005), S. 83-107

Ivaska, Andrew M., Movement Youth in a Global Sixties Hub: The Everyday Lives of Transnational Activists in Postcolonial Dar es Salaam, in: Richard Ivan Jobs/David M. 
Pomfret, Hg., Transnational Histories of Youth in the Twentieth Century, Hampshire 2015, S. $188-210$

Jäger, Helmut, SHIDA KWELI! - Wirklich ein Problem! Zu Frustration und Gejammer vieler

Entwicklungshelfer in Tanzania, in: Blätter des iz3w 98 (1981), S. 49-52

Jahn, Roland, Wir Angepassten. Überleben in der DDR, München 2015

James, C. L. R., State Capitalism and World Revolution, Chicago 1986 [1950]

James, Leslie /Elisabeth Leake, Decolonization and the Cold War: Negotiating Independence, London 2015

Jennings, Michael, „A Very Real War“: Popular Participation in Development in Tanzania During the 1950s \& 1960s, in: International Journal of African Historical Studies 40/1 (2007),

S. $71-95$

Jennings, Michael, Surrogates of the State. NGOs, Development, and Ujamaa in Tanzania, Bloomfield, CT 2008

Jessen, Ralph, Diktatorische Herrschaft als kommunikative Praxis. Überlegungen zum

Zusammenhang von „Bürokratie“ und Sprachnormierung in der DDR-Geschichte, in: Alf Lüdtke/Peter Becker, Hg., Akten, Eingaben, Schaufenster: Die DDR und ihre Texte.

Erkundungen zu Herrschaft und Alltag, Berlin 1997, S. 57-75

Joerges, Bernward, Experten, in: Hans Besters/Ernst E. Boesch, Hg., Entwicklungspolitik. Handbuch und Lexikon, Stuttgart 1966, S. 1127-1135

Johansson, Lars, Ten Million Trees Later. Land Use Change in the West Usambara Mountains the Soil Erosion Control and Agroforestry Project in Lushoto District 1981-2000, Eschborn 2001

Judt, Matthias, Der Bereich Kommerzielle Koordinierung. Das DDR-Wirtschaftsimperium des Alexander Schalck-Golodkowski. Mythos und Realität, Berlin 2013

Judt, Tony, Postwar. A History of Europe Since 1945, New York 2005

K., V./B. W., Praxiserfahrungen aus der Arbeit als Entwicklungshelfer in Tansania, in: Blätter des iz3w 381 (1979), S. 11-15

Kahama, C. G. /T. L. Maliyamkono/Stuart Wells, The Challenge for Tanzania's Economy, London 1986

Kalfelis, Melina, Flexibel aus Armut. Die Lebenswelt von lokalen Entwicklungsakteuren in Burkina Faso vor dem Hintergrund entwicklungspolitischer Erwartungshaltungen, in: Paideuma 61 (2015), S. 117-142

Kalinovsky, Artemy M., The Blind Leading the Blind: Soviet Advisors, Counter-Insurgency and Nation-Building in Afghanistan, in: CWIHP Working Paper Series 60 (2010)

Kamata, Ng'wanza, The Economic Diplomacy of Tanzania. Accumulation by Dispossession in a Peripheral State, in: Agrarian South. Journal of Political Economy 1/3 (2013), S. 291-313

Kapinga, Wilbert B. L., State Control of the Working Class through Labour Legislation, in: Issa G. Shivji, Hg., The State and the Working People in Tanzania, Dakar 1986, S. 87-106

Kaple, Deborah, Agents of Change. Soviet Advisers and High Stalinist Management in China, 1949-1960, in: Journal of Cold War Studies 18/1 (2016), S. 5-30

Kapoor, Ilan, The Devil's in the Theory. A Critical Assessment of Robert Chambers' Work on Participatory Development, in: Third World Quarterly 23/1 (2002), S. 101-117

Karlsch, Rainer, „Weltniveau“. Spitzenleistungen in Technik und Produktion?, in: Thomas Großbölting, Hg., Friedensstaat, Leseland, Sportnation? DDR-Legenden auf dem Prüfstand, Berlin 2009 
Katsakioris, Constantin, Sowjetische Bildungsförderung für afrikanische und asiatische Länder, in: Bernd Greiner u. a., Hg., Macht und Geist im Kalten Krieg, Hamburg 2011, S. 396-415

Katsakioris, Constantin, Creating a Socialist Intelligentsia. Soviet Educational Aid and its Impact on Africa (1960-1991), in: Cahiers d’Études africaines LVII/2 (2017), S. 259-287

Kebschull, Dietrich, FRG and GDR in the Third World, in: Intereconomics 5 (1971), S. 158-160

Kelly, Philip /Tom Lusis, Migration and the Transnational Habitus: Evidence from Canada and the Philippines, in: Environment and Planning A 38 (2006), S. 831-847

Kern, Thorsten, West Germany and Namibia's Path to Independence, 1969-1990: Foreign Policy and Rivalry with East Germany, Basel 2019

Kilian, Werner, Die Hallstein-Doktrin. Der diplomatische Krieg zwischen der BRD und der DDR 1955-1973. Aus den Akten der beiden deutschen Außenministerien, Berlin 2001

Kimambo, Isaria N., Establishment of Teaching Programmes, in: Isaria N. Kimambo u.a., Hg., In Search of Relevance: A History of the University of Dar es Salaam, Dar es Salaam 2008, $107-130$

Kimambo, Isaria N., Establishment of the University of Dar es Salaam, in: Isaria N. Kimambo u. a., Hg., In Search of Relevance: A History of the University of Dar es Salaam, Dar es Salaam 2008, S. 152-169

Kiondo, Andrew S. Z., The Second Economy in Tanzania: its Emergence and Strategies of Control, in: Maria Łoś, Hg., The Second Economy in Marxist States, Basingstoke 1990, S. $175-192$

Kiondo, Andrew S. Z., The Nature of Economic Reforms in Tanzania, in: Horace Campbell/ Howard Stein, Hg., Tanzania and the IMF: The dynamics of Liberalization, Boulder 1992, S. 21-42

Klein, Hans, Vorwort, in: Willi Erl, Hg., Betrifft: Zusammenarbeit: 25 Jahre Deutscher Entwicklungsdienst, Berlin 1988, S. 11-12

Kleinschmidt, Christian/Dieter Ziegler, Hg., Dekolonisierungsgewinner: Deutsche Außenpolitik und Außenwirtschaftsbeziehungen im Zeitalter des Kalten Krieges, Berlin 2018

Kocka, Jürgen, Eine durchherrschte Gesellschaft, in: Hartmut Kaelble u.a., Hg., Sozialgeschichte der DDR, Stuttgart 1994, S. 547-553

Köhler, Jochen, Mittler zwischen den Welten. GTZ - ein Unternehmen in Entwicklung, Opladen 1994

Köhler, Volkmar, Zum Stellenwert Tanzanias in der deutschen Entwicklungszusammenarbeit, in: Ulf Engel u. a., Hg., Tanzania Revisited: Political Stability, Aid Dependency, and Development Constraints, Hamburg 2000

Kohnert Dirk, u.a., Hg., Perspektiven zielorientierter Projektplanung in der Entwicklungszusammenarbeit. München 1992

Kolodzig, Gudrun, Das Erziehungswesen in Tanzania. Historische Entwicklung und Emanzipation von der kolonialen Vergangenheit, Saarbrücken 1978

Koos, Malte, Irgendwie haben wir es doch geschafft, in: Ulrike Ries, Hg., Entwicklungshelfer. Deutsche in der Dritten Welt, Hannover 1971, S. 145-157

Koponen, Juhani, Development for Exploitation. German Colonial Policies in Mainland Tanzania, 1884-1914, Helsinki/Hamburg 1994

Koponen, Juhani, From Dead End to New Lease of Life: Development in South-Eastern Tanganyika from the Late 1930s to the 1950s, in: Joseph Morgan Hodge u.a., Hg., Developing Africa: Concepts and Practices in Twentieth-Century Colonialism, Manchester 2014, S. $37-62$ 
Korbonski, Andrzej/Francis Fukuyama, Hg., The Soviet Union and the Third World. The Last Three Decades, Ithaca 1987

Kothari, Uma, Authority and Expertise. The Professionalisation of International Development and the Ordering of Dissent, in: Antipode 37/3 (2005), S. 425-446

Kothari, Uma, From Colonialism to Development. Reflections of Former Colonial Officers, in: Commonwealth \& Comparative Politics 44/1 (2006), S. 118-136

Kothari, Uma, Spatial Practices and Imaginaries. Experiences of Colonial Officers and Development Professionals, in: Singapore Journal of Tropical Geography 27/3 (2006), S. $235-253$

Kotkin, Stephen, The Kiss of Debt. The Eastern Bloc Goes Borrowing, in: Niall Ferguson u.a., Hg., The Shock of the Global: The 1970s in Perspective, Cambridge, Mass. 2010, S. $80-94$

Kreutzer, Florian /Silke Roth, Einleitung, in: Florian Kreutzer/Silke Roth, Hg., Transnationale Karrieren: Biografien, Lebensführung und Mobilität, Wiesbaden 2006

Krebs, Ursula, Neema. Ein tansanisches Tagebuch einer Entwicklungshelferin, Berlin 1989

Kret, Abigail Judge (2013): „We Unite with Knowledge“: The Peoples’ Friendship University and Soviet Education for the Third World. In: Comparative Studies of South Asia, Africa and the Middle East 33 (2), S. 239-256

Kuchenbuch, David, Globales Interdependenzbewusstsein und die Moralisierung des Alltags in den 1970er und 1980er Jahren, in: Geschichte und Gesellschaft 38/1 (2012), S. 158-184

Küper, Wolfgang, Bildungsförderung - ein Schwerpunkt der Entwicklungshilfe, in: Auslandskurier 11 (1977), S. $18-23$

Kunkel, Sönke /Christoph Meyer, Hg., Aufbruch ins postkoloniale Zeitalter. Globalisierung und die aussereuropäische Welt in den 1920er und 1930er Jahren, Frankfurt am Main 2012

Kunkel, Sönke, Systeme des Wissens, Visionen von Fortschritt: die Vereinigten Staaten, das Jahrzehnt der Modernisierungstheorie und die Planung Nigerias 1954-1965, in: Archiv für Sozialgeschichte 48 (2008), S. 155-182

Lal, Priya, Militants, Mothers and the National Family. Ujamaa, Gender and Rural Development in Postcolonial Tanzania, in: Journal of African History 51/1 (2010), S. 1-20

Lal, Priya, Self-Reliance and the State. The Multiple Meanings of Development in Early PostColonial Tanzania, in: Africa 82/2 (2012), S. $212-234$

Lal, Priya, Maoism in Tanzania: Material Connections and Shared Imaginaries, in: Alexander C. Cook, Hg., Mao's Little Red Book: A Global History, Cambridge 2014, S. 96-116

Lal, Priya, African Socialism in Postcolonial Tanzania, Cambridge 2015

Lal, Priya, African Socialism and the Limits of Global Familyhood. Tanzania and the New International Economic Order in Sub-Saharan Africa, in: Humanity: An International Journal of Human Rights, Humanitarianism, and Development 6/1 (2015), S. 17-31

Landmann, Inge, Aufgeben oder Durchhalten? Physikunterricht in Tansania, in: Willi Erl, Hg., Betrifft: Zusammenarbeit: 25 Jahre Deutscher Entwicklungsdienst, Berlin 1988, S. $191-196$

Lele, Uma J., The Design of Rural Development. Lessons from Africa, Baltimore 1975 Lemke, Bernd, Deutsche Militärhilfe für afrikanische Staaten im Kalten Krieg. Workshop am Militärgeschichtlichen Forschungsamt, Potsdam, 12. Juni 2008, in: Militärgeschichtliche Zeitschrift 67/2 (2008), S. 483-485 
Lepenies, Philipp H., Lernen vom Besserwisser: Wissenstransfer in der „Entwicklungshilfe“ aus historischer Perspektive, in: Hubertus Büschel/Daniel Speich, Hg., Entwicklungswelten: Globalgeschichte der Entwicklungszusammenarbeit, Frankfurt am Main 2009, S. 33-59

Leskien, Jürgen, Ondjango. Ein angolanisches Tagebuch, Berlin 1980

Leskien, Jürgen, Shilumbu, was will er in Afrika!, Berlin 1988

Li, Tania, The Will to Improve. Governmentality, Development, and the Practice of Politics, Durham 2007

Lindenberger, Thomas, Die Diktatur der Grenzen. Zur Einleitung, in: Thomas Lindenberger, Hg., Herrschaft und Eigen-Sinn in der Diktatur: Studien zur Gesellschaftsgeschichte der DDR, Köln 1999, S. $13-44$

Lindenberger, Thomas, Ist die DDR ausgeforscht? Phasen, Trends und ein optimistischer Ausblick, in: ApuZ 24-26 (2014)

Listowel, Judith, The Making of Tanganyika, London 1965

Lofchie, Michael F., Zanzibar: Background to Revolution, Princeton, N. J. 1965

Lofchie, Michael F., The Political Economy of Tanzania. Decline and Recovery, Philadelphia 2014

Loimeier, Roman, Memories of Revolution: Zur Deutungsgeschichte einer Revolution (Sansibar 1964), in: Africa Spectrum 41 (2006), S. 175-197

Loimeier, Roman, Eine Zeitlandschaft in der Globalisierung. Das islamische Sansibar im 19. und 20. Jahrhundert. Global Studies, Bielefeld 2012

Lopes, Rui, West Germany and the Portuguese Dictatorship, 1968-1974: Between Cold War and Colonialism, Houndmills 2014

Long, Norman, Development Sociology: Actor Perspectives, London 2001

Lonsdale, John, Agency in Tight Corners: Narrative and Initiative in African History, in: Journal of African Cultural Studies 13/1 (2000), S. 5-16

Lorenzini, Sara, The Dilemmas of Solidarity - East German Policies in Africa in the Age of Modernization, in: Berthold Unfried/Eva Himmelstoss, Hg., Die eine Welt schaffen: Praktiken von „Internationaler Solidarität“ und „Internationaler Entwicklung“, Leipzig 2012, S. $57-71$

Loxley, John, Monetary Institutions and Class Struggle in Tanzania, in: Bismarck U. Mwansasu/ Cranford Pratt, Hg., Towards Socialism in Tanzania, Dar es Salaam 1979, S. 72-92

Lüders, Klaus, Tansania in der Sicht der Sowjetunion. Eine Studie zur sowjetischen Schwarzafrika-Politik, Hamburg 1978

Lüdtke, Alf/Belinda J. Davis/Thomas Lindenberger, Hg., Alltag, Erfahrung, Eigensinn. Historisch-anthropologische Erkundungen, Frankfurt/Main 2008

Lüdtke, Alf, Sprache und Herrschaft in der DDR. Einleitende Überlegungen, in: Alf Lüdtke/Peter Becker, Hg., Akten, Eingaben, Schaufenster: Die DDR und ihre Texte. Erkundungen zu Herrschaft und Alltag, Berlin 1997, S. 11-28

Lüdtke, Alf, Eigen-Sinn. Fabrikalltag, Arbeitererfahrungen und Politik vom Kaiserreich bis in den Faschismus, Neuaufl., Münster 2015

Luhanga, Matthew Laban /Daniel J. Mkude, Hg., Higher Education Reforms in Africa. The University of Dar es Salaam Experience, Dar es Salaam, Tanzania 2003

Luhanga Matthew L., The Courage for Change: Re-Engineering the University of Dar Es Salaam, Dar es Salaam 2009 
Mac Con Uladh, Damian, Studium bei Freunden? Ausländische Studierende in der DDR bis 1970, in: Christian T. Müller/Patrice G. Poutrus, Hg., Ankunft, Alltag, Ausreise: Migration und interkulturelle Begegnung in der DDR-Gesellschaft, Köln 2005, S. 175-220

Macekura, Stephen J., Of Limits and Growth. The Rise of Global Sustainable Development in the Twentieth Century, New York 2015

Macekura, Stephen J./Erez Manela, Hg. The Development Century: A Global History, Cambridge, 2018

Malisius, Ulrich, Vergessener Reichtum - Altstadtsanierung in Sansibar, in: Willi Erl, Hg., Betrifft: Zusammenarbeit: 25 Jahre Deutscher Entwicklungsdienst, Berlin 1988, S. $184-190$

Maliyamkono, T. L. u.a., Higher Education and Development in Eastern Africa, London 1982

Maliyamkono, T. L. /M. S. D. Bagachwa, The Second Economy in Tanzania, London 1990

Mamdani, Mahmood, Citizen and Subject. Contemporary Africa and the Legacy of Late Colonialism, Princeton 1996

Mamdani, Mahmood, Scholars in the Marketplace. The Dilemmas of Neo-Liberal Reform at Makerere University, 1989-2005, Cape Town 2009

Mapunda, Bertram B.B., Infrastructure, in: Isaria N. Kimambo u.a., Hg., In Search of Relevance: A History of the University of Dar es Salaam, Dar es Salaam 2008, S. 60-82

Maral-Hanak, Irmi, Language, Discourse and Participation. Studies in Donor-Driven Development in Tanzania, Wien 2009

Marcus, George E., Ethnography in/of the World System. The Emergence of Multi-Sited Ethnography, in: Annual Review of Anthropology 24/1 (1995), S. 95-117

Marsland, Rebecca, Community Participation the Tanzanian Way: Conceptual Contiguity or Power Struggle?, in: Oxford Development Studies 34/1 (2006), S. 65-79

Martin, Esmond Bradley, Zanzibar. Tradition and Revolution, London 1978

Martin, Jeannett, Been-To, Burger, Transmigranten? Zur Bildungsmigration von Ghanaern und ihrer Rückkehr aus der Bundesrepublik Deutschland, Münster 2005

Marx, Karl, Der achtzehnte Brumaire des Louis Bonaparte (Werke Band 8), Berlin 1972

Mass, Sandra, „Eine Art sublimierter Tarzan“. Die Ausbildung deutscher Entwicklungshelfer und Entwicklungshelferinnen als Menschentechnik in den 1960er Jahren, in: WerkstattGeschichte 42 (2006), S. 77-89

Matthes, Helmut, Zur Entwicklung der außenpolitischen Grundlagen der Beziehungen zwischen der Deutschen Demokratischen Republik und der Vereinigten Republik Tansania bis Mitte der siebziger Jahre, in: Ulrich van der Heyden/Franziska Benger, Hg., Kalter Krieg in Ostafrika: Die Beziehungen der DDR zu Sansibar und Tansania, Berlin 2009, S. 55-97

Matusevich, Maxim, Journeys of Hope. African Diaspora and the Soviet Society, in: African Diaspora 1/1 (2008), S. 53-85

Maynes, Mary Jo u.a., Telling Stories. The Use of Personal Narratives in the Social Sciences and History, Ithaca 2008

Mazrui, Ali, Tanzaphilia, in: Transition 31 (1967), S. 20-26

Mbwette, T. S. A. /Abel G. M. Ishumi, Hg., Managing University Crises, Dar es Salaam 2000

McHenry, Dean E., Limited Choices. The Political Struggle for Socialism in Tanzania, Boulder 1994

McClellan, Woodford, Black Hajj to „Red Mecca“: Africans and Afro-Americans at KUTV, 1925-1938, in: Maxim Matusevich, Hg., Africa in Russia, Russia in Africa: Three Centuries of Encounters, Trenton, NJ 2007, S. 61-84 
McCracken, John, Terry Ranger: A Personal Appreciation, in: Journal of Southern African Studies 23/2 (1997), S. 175-185

McMillan, Carl H., Multinationals from the Second World. Growth of Foreign Investment by Soviet and East European Enterprises, New York 1987

Mdoe, Michael, The Impact of Rangeland Rehabilitiation in Mbwei Village in the West Usamabara Mountains of Tanzania: Seven Years Experience in Mbwei Village, Lushoto 1989

Mëhilli, Elidor, Socialist Encounters: Albania and the Transnational Eastern Bloc in the 1950s, in: Patryk Babiracki/Kenyon Zimmer, Hg., Cold War Crossings: International Travel and Exchange across the Soviet bloc, 1940s-1960s, Arlington 2014, S. 107-133

Melber, Henning, Hg., The Rise of Africa's Middle Class. Myths, Realities and Critical Engagements, Uppsala/London 2016

Mercer, Claire, The Discourse of Maendeleo and the Politics of Women's Participation on Mount Kilimanjaro, in: Development \& Change 33/1 (2002), S. 101-127

Meier, Lukas, Die Macht des Empfängers. Gesundheit als Verhandlungsgegenstand zwischen der Schweiz und Tansania, 1970-1980, in: Sara Elmer u. a., Hg., Handlungsfeld Entwicklung. Schweizer Erwartungen und Erfahrungen in der Geschichte der Entwicklungsarbeit, Basel 2014, S. 125-144

Meriwether, James H., „Worth a Lot of Negro Votes“. Black Voters, Africa, and the 1960 Presidential Campaign, in: Journal of American History 95/3 (2008), S. 737-763

Merten, Peter, Selbsthilfe und Selbsthilfeförderung im ländlichen Afrika (am Beispiel der Zigua-Gesellschaft), in: Heinz Sahner/Stefan Schwendtner, Hg., 27. Kongreß der Deutschen Gesellschaft für Soziologie - Gesellschaften im Umbruch: Sektionen und Arbeitsgruppen, Opladen 1995, S. 99-103

Messner, Dirk, Entwicklungspolitik als globale Strukturpolitik, in: Thomas Jäger u.a., Hg., Deutsche Außenpolitik: Sicherheit, Wohlfahrt, Institutionen und Normen, 2., aktualisierte und erw. Aufl., Wiesbaden 2011, S. 414-442

Meueler, Erhard, Hg., Unterentwicklung. Wem nützt die Armut der Dritten Welt? Reinbek 1974

Mhina, A. K., The Impact of Tirdep Extension Project in Tanga Region, in: Taamuli: A Political Science Forum 11/1 (1982), S. $27-50$

Middell, Matthias, Weltgeschichte ${ }^{D D R}$. Die DDR in globalgeschichtlicher Perspektive, in: Ulrich Mählert, Hg., Die DDR als Chance. Neue Perspektiven auf ein altes Thema, Berlin 2016, S. $149-156$

Middell, Matthias/Katja Naumann, Global History and the Spatial Turn: From the Impact of Area Studies to the Study of Critical Junctures of Globalization, in: Journal of Global History 5/1 (2010), S. 149-70

Miethe, Ingrid, Bildung und soziale Ungleichheit in der DDR. Möglichkeiten und Grenzen einer gegenprivilegierenden Bildungspolitik, Opladen 2007

Mitchell, Timothy, Rule of Experts. Egypt, Techno-Politics, Modernity, Berkeley 2002

Mittag, Günter, Um jeden Preis. Im Spannungsfeld zweier Systeme, Berlin 2015

Mkandawire, Thandika, Fifty Years of African Independence. Personal Reflections. Distinguished Nyerere Lecturer, Dar es Salaam 2013

Mlimuka, A. K. L. J. /P. J. A. M. Kabudi, The State and the Party, in: Issa G. Shivji, Hg., The State and the Working People in Tanzania, Dakar 1986, S. 58-86

Mohan, Giles /Samuel Hickey, Hg., Participation, From Tyranny to Transformation? Exploring New Approaches to Participation in Development, London 2004 
Molony, Tom, Nyerere. The Early Years, Woodbridge 2014

Monson, Jamie, Africa's Freedom Railway. How a Chinese Development Project Changed Lives and Livelihoods in Tanzania, Bloomington 2009

Mosler, Günter, Als DDR-Auslandskader in Mosambik (1979-1982): Zwischen Dschungel, Taiga, Savanne, Wüste und Heimat, Leipzig 2013

Mosse, David, Cultivating Development. An Ethnography of Aid Policy and Practice, London, Ann Arbor 2005

Mosse, David, Hg., Adventures in Aidland. The Anthropology of Professionals in International Development, New York 2011

Msekwa, Pius, Uongozi na Utawala wa Mwalimu Julius Kambarage Nyerere. Miaka 25 ya Utumishi Wangu kwa Umma Chini ya Ungozi wa Mwalimu Julius Kambarage Nyerere, Dar es Salaam 2012

Mtei, Edwin, From Goatherd to Governor. The Autobiography of Edwin Mtei, Dar es Salaam 2009

Muehlenbeck, Philip, Czechoslovakia in Africa, 1945-1968, New York 2016

Mushi, Philemon Andrew K., History and Development of Education in Tanzania, Dar es Salaam 2009

Müller, Hans Mathias, Die Bildungshilfe der Deutschen Demokratischen Republik, Frankfurt am Main, New York 1995

Müller, Hans, Als DDR-Tierarzt in Tansania, in: Ulrich van der Heyden/Franziska Benger, Hg., Kalter Krieg in Ostafrika: Die Beziehungen der DDR zu Sansibar und Tansania, Berlin 2009, S. $99-110$

Müller, Tanja R., „Memories of Paradise“ - Legacies of Socialist Education in Mozambique, in: African Affairs 109/436 (2010), S. 451-470

Mushi, S. S., Tanzania, in: Adebayo Adedeji, Hg., Indigenization of African Economies, London 1981, S. $204-237$

Mwakikagile, Godfrey, Tanzania under Mwalimu Nyerere: Reflections on an African Statesman, Dar es Salaam 2006

Mwansasu, Bismarck U., The Changing Role of the Tanganyika African National Union, in: Bismarck U. Mwansasu/Cranford Pratt, Hg., Towards Socialism in Tanzania, Dar es Salaam 1979, S. $169-192$

Nugent, Paul, Africa since Independence. A Comparative History, 2. Aufl., Basingstoke 2012

Nayar, Deepak, Hg., Economic Relations between Socialist Countries and the Third World, London 1977

Niederhut, Jens, Die Reisekader. Auswahl und Disziplinierung einer privilegierten Minderheit in der DDR, Leipzig 2005

Nieswand, Boris, Theorising Transnational Migration. The Status Paradox of Migration, New York 2011

Nieswand, Boris, Der Migrations-Entwicklungs-Nexus in Afrika. Diskurswandel und Diasporaformation, in: Tatjana Baraulina u.a., Hg., Potenziale der Migration zwischen Afrika und Deutschland, Nürnberg 2011, S. 400-425

Nindi, B. C., Traditional Agricultural Extension System in Tanzania: A Critical Analysis, in: Journal of Eastern Africa Research and Development 16 (1986), S. 122-132

Nsekela, A. S., The Public Enterprise an an Instrument of Economic Development in Tanzania, in: Gabriel Ruhumbika, Hg., Towards Ujamaa: Twenty years of TANU leadership, A 
contribution of the University of Dar-es-Salaam to the $20^{\text {th }}$ Anniversary of TANU, Nairobi, Kampala, Dar es Salaam 1974, S. 108-147

Nsekela, A. S., Socialism and Social Accountability in a Development Nation. Problems in the Transformation of the Tanzanian Economy and Society, Nairobi 1978

Nunan, Timothy, Humanitarian Invasion. Global Development in Cold War Afghanistan, New York 2016

Nuscheler, Franz, Lern- und Arbeitsbuch Entwicklungspolitik, 5., aktualisierte Auflage, Dietz 2011

Nyerere, Julius, Freedom and Socialim / Uhuru na Ujamaa. A Selection from Writings and Speeches 1965-1968, Dar es Salaam 1968

Nyerere, Julius, The Varied Paths to Socialism. Address to Cairo University, 10 April 1967. In: Ujamaa. Essays on Socialism, Dar es Salaam 1968

Nyerere, Julius, Freedom and Development. A Selection from Writings and Speeches 1968-1973, Dar es Salaam 1973

Nyerere, Julius, Capitalism or Socialism: The Rational Choice, in: New Blackfriars 55/653 (1974), S. 440-448

Olivier de Sardan, Jean-Pierre, Anthropology and Development. Understanding Contemporary Social Change, London, New York 2005

Othman, Haroub, From Law to Development Studies: A View from Tanzania, in: The Institute of Development Studies, Annual Report 1986 / Handbook 1987, Sussex 1987

Paget, Dan, Again, Making Tanzania Great: Magufuli's Restorationist Developmental Nationalism, in: Democratization (2020), S. 1- 22

Pallotti, A., Post-Colonial Nation-Building and Southern African Liberation: Tanzania and the Break of Diplomatic Relations with the United Kingdom, 1965-1968, African Historical Review, 41/2 (2009), S. 60-84

Parfitt, Trevor, The Ambiguity of Participation. A Qualified Defence of Participatory Development, in: Third World Quarterly 25/3 (2004), S. 537-555

Parsons, Timothy, The 1964 Army Mutinies and the Making of Modern East Africa, Westport, CT 2003

Pater, Siegfried, Hg., Etwas geben - viel nehmen. Entwicklungshelfer berichten, 3. Aufl., Bonn 1982

Pater, Siegfried, Vorwort, in: ders., Hg., Etwas geben - viel nehmen: Entwicklungshelfer berichten, 3. Aufl., Bonn 1982, S. 5-7

Pater, Siegfried, Stichwort: Wende. Konservative Entwicklungspolitik seit den Achtzigern, 2., vollst. überarb. Aufl., Bad Honnef 1990

Pearson, Ruth, The Rise and Rise of Gender and Development, in: Uma Kothari, Hg., A Radical History of Development Studies: Individuals, Institutions and Ideologies, Cape Town, London, New York 2005, S. 157-179

Pesek, Michael, Koloniale Herrschaft in Deutsch-Ostafrika. Expeditionen, Militär und Verwaltung seit 1880, Frankfurt am Main 2005

Peter, Chris /Sengondo Mvungi, The State and the Student Struggles, in: Issa G. Shivji, Hg., The State and the Working People in Tanzania, Dakar 1986, S. 155-194

Péteri, György, Nylon Curtain - Transnational and Transsystemic Tendencies in the Cultural Life of State-Socialist Russia and East-Central Europe, in: Slavonica 10/2 (2013), S. 113-123 
Peters, Rebecca Warne, Development Mobilities: Identity and Authority in an Angolan Development Programme, in: Journal of Ethnic and Migration Studies 39/2 (2013), S. $277-293$

Petterson, Donald, Revolution in Zanzibar. An American's Cold War Tale, Boulder 2002 Pfeffer, Clemens, Missionshistoriographie post 1968. Postkoloniale Perspektiven avant la lettre, in: Sebastian Pittl, Hg., Theologie und Postkolonialismus. Ansätze Herausforderungen - Perspektiven. Regensburg 2018, S. 191-218

Philips, Kristin, Dividing the Labor of Development: Education and Participation in Rural Tanzania, in: Comparative Education Review 57/4 (2013), S. 637-661

Pieterse, Jan Nederveen, Development Theory. Deconstructions/Reconstructions, London 2010

Pilgram, Klaus / Karl-Ludwig Zils, Tanga Integrated Rural Development Programme (TIRDEP): Experience with Regional Planning and Project Implementation in Tanga Region, Tanzania, Tanga, Eschborn 1980

Pitcher, M. Anne /Kelly M. Askew, African Socialisms and Postsocialisms, in: Africa 76/1 (2006), S. 1-14

Polanyi, Karl, The Great Transformation. Politische und ökonomische Ursprünge von Gesellschaften und Wirtschaftssystemen, Berlin 2015 [1944]

Pollvogt, Renate, Zur Anatomie einer entwicklungspolitischen Organisation - die GTZ. Genese und Struktur der Deutschen Gesellschaft für Technische Zusammenarbeit (GTZ), Saarbrücken 1987

Porsche-Ludwig, Markus, 50 Jahre BMZ: Von Entwicklungshilfe über Entwicklungspolitik bis zur Entwicklungszusammenarbeit, in: Wolfgang Gieler, Hg., 50 Jahre deutsche Entwicklungszusammenarbeit: Das BMZ von Walter Scheel bis Dirk Niebel, Bonn 2011, S. $247-263$

Portelli, Alessandro, The Death of Luigi Trastulli and Other Stories: Form and Meaning in Oral History, Albany 1990

Poutrus, Patrice G., Aufnahme in die „geschlossene Gesellschaft“: Remigranten, Übersiedler, ausländische Studierende und Arbeitsmigranten in der DDR, in: Jochen Oltmer, Hg., Handbuch Staat und Migration in Deutschland seit dem 17. Jahrhundert, Berlin, Boston 2016, S. $967-995$

Prashad, Vijay, The Darker Nations. A People's History of the Third World, New York, London 2008

Pratt, Cranford, The Critical Phase in Tanzania, 1945-1968. Nyerere and the Emergence of a Socialist Strategy, Cambridge 1976

Proctor, J. H., Hg., The Cell System of the Tanganyika African National Union, Dar es Salaam 1971

Pugach, Sara, African Students in Cold War Leipzig: Using University Archives to Recover a Forgotten History, in: Geert Castryck u.a., Hg., Sources and Methods for African History and Culture: Essays in Honour of Adam Jones, Leipzig 2016, S. 541-564

Pugach, Sara, Eleven Nigerian Students in Cold War East Germany: Visions of Science, Modernity, and Decolonization, in: Journal of Contemporary History 54/3 (2019), 551-572

Rakelmann, Georgia A., Expertenkultur, in: Dietmar Dirmoser u.a., Hg., Mythos Entwicklungshilfe: Entwicklungsruinen: Analysen und Dossiers zu einem Irrweg, Giessen 1991, S. $157-174$

Rattansi, Ali, Racism. A Very Short Introduction, Oxford 2007

Rauch, Theo, Entwicklungspolitik. Theorien, Strategien, Instrumente, Braunschweig 2009 
Reichardt, Sven, Bourdieus Habituskonzept in den Geschichtswissenschaften, in: Alexander Lenger u.a., Hg., Pierre Bourdieus Konzeption des Habitus, Wiesbaden 2013, S. 307-323 Ries, Ulrike, Hg., Entwicklungshelfer. Deutsche in der Dritten Welt, Hannover 1971

Ries, Ulrike, Vorwort, in: dies., Hg., Entwicklungshelfer. Deutsche in der Dritten Welt, Hannover 1971, S. 7-18

Rist, Gilbert, The History of Development. From Western origins to Global Faith, London, New York 2008

Robert, Shaaban, Maisha Yangu na Baada ya Miaka Hamsini, Dar es Salaam, 2013

Roberts, George, The Assassination of Eduardo Mondlane. FRELIMO, Tanzania, and the Politics of Exile in Dar es Salaam, in: Cold War History 17/1 (2016), S. 1-19

Roberts, George, Press, Propaganda, and the German Democratic Republic's Search for Recognition in Tanzania, 1964-1972, in: Philip E. Muehlenbeck/Natalia Telepneva, Warsaw Pact Intervention in the Third World: Aid and Influence in the Cold War, London 2018, S. $148-172$

Rodney, Walter, Tanzanian Ujamaa and Scientific Socialism, in: The African Review: A Journal of African Politics Development and International Affairs 1/4 (1971), S. 61-76

Röhnelt, Gerd, Die bundesdeutsche Entwicklungshilfe für Tansania seit 1961: regionale Bedeutung und gesamtwirtschaftlicher Nutzen, Frankfurt am Main 1980

Roth, Silke, The Paradoxes of Aid Work: Passionate Professionals, London, New York 2015

Rottenburg, Richard, Weit hergeholte Fakten. Eine Parabel der Entwicklungshilfe, Stuttgart 2002

Routley, Laura, Developmental States in Africa? A Review of Ongoing Debates and Buzzwords, in: Development Policy Review 32/2 (2014), S. 159-177

Rugumamu, Severine M., Lethal Aid. The Illusion of Socialism and Self-Reliance in Tanzania, Trenton, NJ 1997

Rupprecht, Tobias, Gestrandetes Flaggschiff. Die Moskauer Universität der Völkerfreundschaft. In: Osteuropa 1 (2010), S. 95-114

Rweyemamu, Justinian, Underdevelopment and Industrialization in Tanzania, Nairobi 1973

Sabea, Hanan, Codifying Manamba. History, Knowledge Production and Sisal Plantation Workers in Tanzania, in: Journal of Historical Sociology 23/1 (2010), S. 144-170

Sabrow, Martin, Die DDR zwischen Geschichte und Gedächtnis, in: Christian Ernst, Hg., Geschichte im Dialog?: „DDR-Zeitzeugen“ in Geschichtskultur und Bildungspraxis, Schwalbach am Taunus 2014, S. 23-37

Sadleir, Randal, Tanzania: Journey to Republic. London, New York 1999

Saint Martin, Monique de u.a., Hg., Étudier à l'Est. Expériences de diplômés africains, Paris 2015

Saint Martin, Introduction, in: dies. u. a., Hg., Étudier à l'Est. Expériences de diplômés africains, Paris 2015, S. $17-33$

Salah Ovadia, Jesse, The Petro-Developmental State in Africa. Making Oil Work in Angola, Nigeria and the Gulf of Guinea, London 2016

Salheiser, Axel, Parteitreu, plangemäß, professionell? Rekrutierungsmuster und Karriereverläufe von DDR-Industriekadern, Wiesbaden 2009

Samoff, Joel, Theory and Practice in the Analysis of Tanzanian Liberalization: A Comment, in: Horace Campbell/Howard Stein, Hg., Tanzania and the IMF: The Dynamics of Liberalization, Boulder 1992, S. 171-188 
Sassoon, Joseph, The East German Ministry for State Security and Iraq, 1968-1989, in: Journal of Cold War Studies 16/1 (2014), S. 4-23

Saul, John S., Planning for Socialism in Tanzania: The Socio-Political Context, in: J. F.

Rweyemamu u. a., Hg., Towards Socialist Planning, Dar es Salaam 1972, S. 1-29

Saul, John S., The Failure of African Socialisms and Their Future, in: Robert Albritton, Hg., New

Socialisms: Futures Beyond Globalization, London 2004, S. 159-181

Saul, John S., Revolutionary Traveller. Freeze-Frames from a Life, Winnipeg 2009

Schaad, Isolde, Knowhow am Kilimandscharo, Zürich 1984

Schaad, Isolde, Die Komfortzelle im Busch, in: Dietmar Dirmoser u.a., Hg., Mythos

Entwicklungshilfe: Entwicklungsruinen: Analysen und Dossiers zu einem Irrweg, Giessen 1991, S. $175-184$

Schenck, Marcia C., From Luanda and Maputo to Berlin. Uncovering Angolan and Mozambican Migrants' Motives to Move to the German Democratic Republic (1979-1990), in: African Economic History 44 (2016), S. 202-234

Scherzer, Landolf, Das Camp von Matundo. 132 Tage Afrika, Berlin 1986

Scherzer, Landolf, Die Fremden. Unerwünschte Begegnungen und verbotene Protokolle, Berlin 2002

Schicho, Walter, Handbuch Afrika. Band 3: Nord- und Ostafrika. Frankfurt am Main 2004

Schicho, Walter, Ujamaa: Sozialismus und/oder Entwicklung, in: Joachim Becker/Rudy Weissenbacher, Hg., Sozialismen: Entwicklungsmodelle von Lenin bis Nyerere, Wien 2009, S. $175-188$

Schleicher, Hans-Georg, Afrika in der Außenpolitik der DDR, in: Ulrich van der Heyden u.a., Hg., Die DDR und Afrika: Zwischen Klassenkampf und neuem Denken, Münster 1993, $10-30$

Schleicher, Hans-Georg, Entwicklungszusammenarbeit und Außenpolitik der DDR, in: Hans-Jörg Bücking, Hg., Entwicklungspolitische Zusammenarbeit in der Bundesrepublik Deutschland und der DDR, Berlin 1998, 95-110

Schleicher, Hans-Georg, GDR Solidarity: The German Democratic Republic and the South African Liberation Struggle, in: South African Democracy Education Trust, Hg., The Road to Democracy in South Africa, Pretoria 2004, S. 1069-1153

Schmelz, Andrea, Bildungsmigranten aus Afrika und Asien. Interkulturalität, Umbrüche und Neuorientierungen im geteilten und wiedervereinigten Deutschland, Frankfurt am Main, London 2004

Schmelzer, Matthias, The Hegemony of Growth. The OECD and the Making of the Economic Growth Paradigm, Cambridge 2016

Schmidt, Heide-Irene, Pushed to the Front: The Foreign Assistance Policy of the Federal Republic of Germany, 1958-1971, in: Contemporary European History 12/4 (2003),

S. 473-507

Schneider, Leander, The Tanzania National Archives, in: History in Africa Vol. 30 (2003), S. 447-454

Schneider, Leander, Government of Development. Peasants and Politicians in Postcolonial Tanzania, Bloomington 2014

Schneider-Barthold, Wolfgang, Tanzania. Voraussetzungen und Möglichkeiten der privaten Investition einschließlich der Darstellung des parastaatlichen Sektors, Hamburg 1974 
Schnitzer, Klaus, u.a., Probleme und Perspektiven des Ausländerstudiums in der Bundesrepublik Deutschland. Untersuchung über Studienverlauf, Studienbedingungen, soziale Lage und Reintegration von Studenten aus Entwicklungsländern, Hannover 1986.

Schruhl, Klaus Dieter, Sabah heißt Morgenröte - als Arzt in der VDR Jemen, Leipzig 1981

Schott, Hanna, Matomora Matomora. Der längste Umweg führt nach Hause, Schwarzenfeld 2012

Schuknecht, Rohland, British Colonial Development Policy after the Second World War: The Case of Sukumuland, Tanganyika, Berlin 2010

Schulz, Brigitte H. /William W. Hansen, Hg., The Soviet Bloc and the Third World. The Political Economy and East-South Relations, Boulder 1989

Schulz, Brigitte H., Development Policy in the Cold War Era. The Two Germanies and SubSaharan Africa, 1960-1985, Münster 1995

Schwingel, Markus, Pierre Bourdieu zur Einführung, 7., erg. Aufl., Hamburg 2011

Scott, James C., Weapons of the Weak. Everyday Forms of Peasant Resistance, New Haven 1985

Scott, James C., Domination and the Arts of Resistance. Hidden Transcripts, New Haven 1990

Scott, James C., Seeing Like a State. How Certain Schemes to Improve the Human Condition Have Failed, New Haven 1998

Sebald, Peter, Völkerfreundschaft oder Auslandsinformation. Impressionen zum Wirken der Deutsch-Afrikanischen Gesellschaft., in: Ulrich van der Heyden u.a., Hg., Die DDR und Afrika: Zwischen Klassenkampf und neuem Denken, Münster 1993, S. 79-94

Seibert, Niels, Vergessene Proteste. Internationalismus und Antirassismus 1964-1983, Münster 2008

Seiler, Max, Vergleich der Lateinamerikapolitik von Bundesrepublik Deutschland und DDR am Beispiel Nicaragua (1979-1989). Unter besonderer Berücksichtigung der jeweiligen Bündnispolitik von USA und UdSSR, Marburg 1995

Shachtman, Tom, Airlift to America. How Barack Obama, Sr., John F. Kennedy, Tom Mboya, and 800 East African Students Changed Their World and Ours, New York 2010

Shafi, Adam, Mbali na Nyumbani, Nairobi 2013

Sharma, Patrick Allan, Robert McNamara's Other War: The World Bank and International Development, Philadelphia 2017

Shivji, Issa G., Class Struggles in Tanzania, London 1978

Shivji, Issa G., Hg., The State and the Working People in Tanzania, Dakar 1986

Shivji, Issa G., Introduction: The Transformation of the State and the Working People, in: ders., Hg., The State and the Working People in Tanzania, Dakar 1986, S. 1-15

Shivji, Issa G., The Politics of Liberalization in Tanzania: The Crisis of Ideological Hegemony, in: Horace Campbell/Howard Stein, Hg., Tanzania and the IMF: The Dynamics of Liberalization, Boulder 1992, S. 43-58

Shivji, Issa G., Intellectuals at the Hill. Essays and Talks 1969-1993, Dar es Salaam 1993

Shivji, Issa G., Pan-Africanism or Pragmatism? Lessons of the Tanganyika-Zanzibar Union, Dar es Salaam 2008

Sicherman, Carol, Becoming an African University. Makerere, 1922-2000, Trenton 2005

Sieder, Reinhard, Die Rückkehr des Subjekts in den Kulturwissenschaften, Wien 2004

Simpson, Bradley R., Economists with Guns. Authoritarian Development and U.S.-Indonesian Relations, $1960-1968$, Stanford 2008 
Slobodian, Quinn, Bandung in Divided Germany. Managing Non-Aligned Politics in East and West, 1955-63, in: The Journal of Imperial and Commonwealth History 41/4 (2013), S. $644-662$

Slobodian, Quinn, Dissident Guests: Afro-Asian Students and Transnational Activism in the West German Protest Movement, in: Wendy Pojmann, Hg., Migration and Activism in Europe since 1945, New York 2008, S. 33-56

Slobodian, Quinn, Foreign Front. Third World Politics in Sixties West Germany, Durham, NC 2012

Slobodian, Quinn, The Maoist Enemy. Chinas Challenge in 1960s East Germany, in: Journal of Contemporary History 51/3 (2016), S. 635-659

Smith, Daniel Jordan, Patronage, Per Diems and the „Workshop Mentality“: The Practice of Family Planning Programs in Southeastern Nigeria, in: World Development 31/4 (2003), S. $703-715$

Smith, Tony, New Bottles for New Wine. A Pericentric Framework for the Study of the Cold War, in: Diplomatic History 24/4 (2000), S. 567-591

Spanger, Hans-Joachim / Lothar Brock, Die beiden deutschen Staaten in der Dritten Welt. Die Entwicklungspolitik der DDR. Eine Herausforderung für die Bundesrepublik Deutschland?, Opladen 1987

Speich, Daniel, The Kenyan Style of „African Socialism“: Developmental Knowledge Claims and the Explanatory Limits of the Cold War, in: Diplomatic History 33/3 (2009), S. $449-466$

Speller, Ian, An African Cuba? Britain and the Zanzibar Revolution, 1964, in: Journal of Imperial and Commonwealth History 35/2 (2007), S. 283-302

Sperling, Jan Bodo, Die Rourkela-Deutschen. Probleme der Verhaltensweisen deutscher Techniker auf einer Grossbaustelle in Indien, Dissertation, Aachen 1965

Spitzberg, Irving J., Introduction, in: Irving J. Spitzberg, Hg., Exchange of Expertise: The Counterpart System in the New International Order, Boulder 1978, S. 1-17

Steiner, André, Von Plan zu Plan. Eine Wirtschaftsgeschichte der DDR, München 2004

Stockmann, Reinhard u.a., Entwicklungspolitik. Theorien - Probleme - Strategien. Lehr- und Handbücher der Politikwissenschaft, München 2010.

Stockmann, Reinhard, Administrative Probleme staatlicher Entwicklungszusammenarbeit Entwicklungsengpässe im Bundesministerium für wirtschaftliche Zusammenarbeit, in: Manfred Glagow, Hg., Deutsche und internationale Entwicklungspolitik: Zur Rolle staatlicher, supranationaler und nicht-regierungsabhängiger Organisationen im Entwicklungsprozeß der Dritten Welt, Opladen 1990, S. 35-75

Storkmann, Klaus, Geheime Solidarität. Militärbeziehungen und Militärhilfen der DDR in die „Dritte Welt“, Berlin 2012

Szuca, Peter B., Tanzania - Land des Ujamaa, in: Ulrike Ries, Hg., Entwicklungshelfer. Deutsche in der Dritten Welt, Hannover 1971, S. 195-213

Temu, Arnold /Bonaventure Swai, Historians and Africanist History: A Critique, London 1981 Temu, Arnold u. a., Tanzania and the Liberation Struggle of Southern Africa, 1961 to 1994, in: Arnold J. Temu/Joel das Neves Tembe, Hg., Southern African Liberation Struggles: Contemporaneous Documents, 1960-1994, Volume 6 (Frontline States - Continued), Dar es Salaam 2014, S. 5-78

Temu, Peter E., The Employment of Foreign Consultants in Tanzania: Its Value and Limitations, in: The African Review 3 (1973), S. 69-84 
Tetzlaff, Rainer, Koloniale Entwicklung und Ausbeutung: Wirtschafts- und Sozialgeschichte Deutsch-Ostafrikas 1885-1914, Berlin 1970

Tetzlaff, Rainer, Der begrenzte Handlungsspielraum der tansanischen Staatsklasse zur Überwindung von Abhängigkeit und Unterentwicklung: Zum Verhältnis von Bürokraten und Bauern, in: Werner Pfennig u.a., Hg., Entwicklungsmodell Tansania, Sozialismus in Afrika: Geschichte, Ökonomie, Politik, Erziehung, Frankfurt/Main, New York 1980, S. $42-68$

Ther, Philipp, Die neue Ordnung auf dem alten Kontinent. Eine Geschichte des neoliberalen Europa, Berlin 2014

Thomas, Clive Y., Dependence and Transformation: Economics of the Transition to Socialism, New York 1974

Thompson, Graham, The Bewitchment and Fall of a Village Politician, in: R. G. Abrahams, Hg., Villagers, Villages and the State in Modern Tanzania, Cambridge 1985, S. 110-134

Thompson, Willard S., Ghana's Foreign Policy, 1957-1966, Princeton 1969

Tordoff, William /Ali A. Mazrui, The Left and the Super-Left in Tanzania, in: The Journal of Modern African Studies 10/3 (1972), S. 427-445

Trentin, Massimiliano, „Tough Negotiations“. The Two Germanys in Syria and Iraq, 1963-74, in: Cold War History 8/3 (2008), S. 353-380

Trentin, Massimiliano, Modernization as State Building: The Two Germanies in Syria, 1963-1972, in: Diplomatic History 33/3 (2009), 487-505

Trentin, Massimiliano, Engineers of Modern Development. East German Experts in Ba'thist Syria, 1965-1972, Padova 2010

Tripp, Aili Mari, Changing the Rules. The Politics of Liberalization and the Urban Informal Economy in Tanzania, Berkeley 1997

Tschannerl, Gerhard, Rural Water Supply in Tanzania: Is Politics or Technique in Command?, in: Andrew Coulson, Hg., African Socialism in Practice. The Tanzanian Experience, Nottingham 1979, S. 86-105

Unfried, Berthold, EntwicklungsexpertInnen: Andere entwickeln. Sich selbst entwickeln?, in: Journal für Entwicklungspolitik XXVI/3 (2010), S. 4-13

Unfried, Berthold, Instrumente und Praktiken von „Solidarität“ Ost und „Entwicklungshilfe“ West: Blickpunkt auf das entsandte Personal, in: Berthold Unfried/Eva Himmelstoss, Hg., Die eine Welt schaffen: Praktiken von „Internationaler Solidarität“ und „Internationaler Entwicklung“, Leipzig 2012, S. 73-98

Unfried, Berthold, Scènes de la vie quotidienne des coopérants de la RDA en Afrique: normes de comportement et transgressions, in: Outre-Mers. Revue d'histoire 384-385 (2014), S. $247-266$

Unfried, Berthold, Instrumente und Praktiken; Friendship and Education, Coffee and Weapons. Exchanges between Socialist Ethiopia and the German Democratic Republic, in: Northeast African Studies 1/2016, S. $15-38$

Unfried, Berthold, A Cuban Cycle of Developmental Socialism? Cubans and East Germans in the Socialist World System, in: Journal für Entwicklungspolitik 33/3 (2017), S. 69-90

Unger, Corinna R., The United States, Decolonization, and the Education of Third World Elites, in: Jost Dülffer/Marc Frey, Hg., Elites and decolonization in the twentieth century. Houndmills, Basingstoke, Hampshire 2011, S. 241-261

Unger, Corinna R., Entwicklungspfade in Indien. Eine internationale Geschichte 1947-1980, Göttingen 2015 
Unger, Corinna R., International Development: A Postwar History, London, 2018

Utz, Robert J., Coordination of Economic Policy Formation and Implementation, in: Robert J. Utz, Hg., Sustaining and Sharing Economic Growth in Tanzania, Washington D.C. 2008, S. $303-312$

Van Beusekom, Monica M. /Dorothy L. Hodgson, Lessons Learned? Development Experiences in the Late Colonial Period, in: The Journal of African History 41/1 (2000), S. 29-33

Van Beusekom, Monica M., Negotiating Development. African Farmers and Colonial Experts at the Office du Niger, 1920-1960, Portsmouth 2002

van der Heyden, Ulrich /Franziska Benger, Hg., Kalter Krieg in Ostafrika. Die Beziehungen der DDR zu Sansibar und Tansania, Berlin 2009

van der Heyden, Ulrich u. a., Hg., Engagiert für Afrika. Die DDR und Afrika II, Münster 1994 van der Heyden, Ulrich, FDJ-Brigaden der Freundschaft aus der DDR - die Peace Corps des Ostens?, in: Berthold Unfried/Eva Himmelstoss, Hg., Die eine Welt schaffen: Praktiken von „Internationaler Solidarität“ und „Internationaler Entwicklung“, Leipzig 2012,

S. $99-122$

van Laak, Dirk, Imperiale Infrastruktur. Deutsche Planungen für eine Erschliessung Afrikas 1880 bis 1960, Paderborn 2004

Vinnai, Volker, Die Arbeit der Friedrich-Ebert-Stiftung in Tansania - 40 Jahre Zusammenarbeit mit Parteien, Gewerkschaften, Zivilgesellschaft und Regierung, in: Norbert von Hofmann u. a., Hg., Die Arbeit der Friedrich-Ebert-Stiftung in Indonesien, Tansania und Zentralamerika seit den 1960er Jahren, Bonn 2010, S. 105-202

von Freyhold, Michaela, The Post-Colonial State and Its' Tanzanian Version, in: Review of African Political Economy 8 (1977), S. 75-89

von Freyhold, Michaela, Ujamaa Villages in Tanzania. Analysis of a Social Experiment, London 1979

von Oppen, Achim, „Hilfe zur Selbsthilfe“ als Geschichte und Anti-Geschichte. Deutschdeutsche Entwicklungshilfe im postkolonialen Afrika, in: Neue Politische Literatur 61/2 (2015), S. $185-202$

Weber, Hermann, Die DDR 1945-1990, 5., aktualisierte Auflage, München 2012

Weis, Toni, The Politics Machine: On the Concept of „Solidarity“ in East German Support for SWAPO, in: Journal of Southern African Studies 37/2 (2011), S. 351-367

Weiser, Ewald, DDR-Lehrer nach Sansibar, in: Ulrich van der Heyden/Franziska Benger, Hg., Kalter Krieg in Ostafrika: Die Beziehungen der DDR zu Sansibar und Tansania, Berlin 2009, S. $213-250$

Weiser, Ewald, Hg., DDR-Bildungshilfe in Äthiopien. Interaktive Erkenntnisse, Erfahrungen und Eindrücke, Berlin/Münster 2013

Wenner, Kate, Shamba Letu. Kibbuz in Afrika, Erlangen 1971

Werner, Michael /Bénédicte Zimmermann, Beyond Comparison: Histoire croisée and the Challenge of Reflexivity, in: History and Theory 45/1 (2006), S. 30-50

Westad, Odd Arne, The Global Cold War. Third World Interventions and the Making of Our Times, New York 2005

White, Luise, Hodgepodge Historiography: Documents, Itineraries, and the Absence of Archives, in: History in Africa 42 (2015), S. 309-318

Whitfield, Lindsay /Alastair Fraser, Negotiating Aid, in: Lindsay Whitfield, Hg., The Politics of Aid: African Strategies for Dealing with Donors, Oxford, New York 2009, S. 27-44 
Wiedmann, Roland, Probleme der Studienfinanzierung in der Deutschen Demokratischen Republik, in: Hans F. Illy/Wolfgang Schmidt-Streckenbach, Hg., Studenten aus der Dritten Welt in beiden deutschen Staaten, Berlin 1987, S. 149-157

Wield, David / Carol Barker, Science, Technology and Development: Part of a Course in Development Studies for First and Second Year Engineering and Medical Students at the University of Dar Es Salaam, Tanzania, in: Social Studies of Science 8 (1978), S. 385-395

Wield, David, Coordination of Donors in African Universities, in: Higher Education Policy 10/1 (1997), S. 41-54

Williams, Glyn, Evaluating Participatory Development. Tyranny, Power and (Re)Politicisation, in: Third World Quarterly 25/3 (2004), S. 557-578

Wilson, Amrit, The Threat of Liberation. Imperialism and Revolution in Zanzibar, London 2013 Wimmelbücker, Ludger, Architecture and City Planning Projects of the German Democratic Republic in Zanzibar, in: The Journal of Architecture 17/3 (2012), S. 407-432

Winrow, Gareth M., The Foreign Policy of the GDR in Africa, Cambridge 2009

Wirth, Heinz, Aspekte des Zusammenhangs von Entwicklungshilfe und Entwicklungsplanung in Tansania, Dissertation, Bonn 1985

Wirz, Albert, Einleitung. Körper, Raum und Zeit der Herrschaft, in: Katrin Bromber u.a., Hg., Alles unter Kontrolle! Disziplinierungsprozesse im kolonialen Tansania (1850-1960), Köln 2003

Wöhlk, Günter, Warten auf Koffern - Hallstein-Doktrin in Tansania, in: Willi Erl, Hg., Betrifft: Zusammenarbeit: 25 Jahre Deutscher Entwicklungsdienst, Berlin 1988, S. 52-56

Wolf, Markus, Spionagechef im geheimen Krieg. Erinnerungen, München 1997

Woll, Artur, Multilaterale und bilaterale Entwicklungshilfe, in: Hans Besters/Ernst E. Boesch, Hg., Entwicklungspolitik. Handbuch und Lexikon, Stuttgart 1966, S. 765-810

Wolle, Stefan, Die heile Welt der Diktatur. Alltag und Herrschaft in der DDR 1971-1989, Bonn 1999

Wolle, Stefan, Der Traum von der Revolte. Die DDR 1968, Berlin 2008

Worby, Eric, „Discipline without oppression“: Sequence, Timing \& Marginality in Southern Rhodesia's Post-War Development Regime, in: The Journal of African History 41/1 (2000), S. $101-125$

Wuyts, Marc, Issa Shivji, in: Development and Change 39/6 (2008), S. 1079-1090

Yengo, Patrice, Jalons pour une historiographie des élites africaines formées dans le Bloc soviétique, in: Michèle Leclerc-Olive, Hg., Les mondes universitaires face au marché. Circulation des savoirs et pratiques des acteurs, Paris 2011, S. 135-148

Zatlin, Jonathan R., Scarcity and Resentment. Economic Sources of Xenophobia in the GDR, 1971-1989, in: Central European History 40/4 (2007), S. 683-720

Zell, Helmut, Angepaßte Technologie: Entwicklungschance oder Sackgasse für die Dritte Welt? Erfahrungen aus Tanzania, in: iz3w 187 (1993), S. 39-42

Zeller, Joachim/Oumar Diallo, Einführung: Das afropolitane Berlin, in: Oumar Diallo/Joachim Zeller, Hg., Black Berlin. Die deutsche Metropole und ihre afrikanische Diaspora in Geschichte und Gegenwart, 2., überarbeitete Auflage, Berlin 2014, S. 11-30

Ziai, Aram, Globale Strukturpolitik? Die Nord-Süd-Politik der BRD und das Dispositiv der Entwicklung im Zeitalter von neoliberaler Globalisierung und neuer Weltordnung, Münster 2007

Ziai, Aram, Post-Development: Premature Burials and Haunting Ghosts, in: Development and Change 46/4 (2015), S. 833-854 
Zürcher, Markus, Ausgehandelte Entwicklung: Widersprüche und Konflikte im Alltagsleben eines Schweizer Ehepaars in Ruanda um 1970, in: Sara Elmer u.a., Hg., Handlungsfeld Entwicklung. Schweizer Erwartungen und Erfahrungen in der Geschichte der Entwicklungsarbeit, Basel 2014, S. 19-44

Zürcher, Markus, Die Schweiz in Ruanda. Mission, Entwicklungshilfe und nationale Selbstbestätigung (1900-1975), Zürich 2014

\section{B.3 Internetquellen}

BMZ, Rede von Bundesminister Gerd Müller vor der Kommission der Afrikanischen Union: Vorstellung der Eckpunkte für einen Marshall-Plan mit Afrika am 4. April 2017 in Addis Abeba. t1p.de/eOur [Kurz-URL]

BMZ, Rede des Parlamentarischen Staatssekretärs Thomas Silberhorn (BMZ) am 12. Mai 2017 bei der IHK Nürnberg für Mittelfranken. t1p.de/mfj5 [Kurz-URL]

Bromber, Katrin u.a., „The Possibilities are Endless“: Progress and the Taming of Contingency, in: ZMO Programmatic Texts 9 (2015). zmo.de/publikationen/ProgramaticTexts/ progress2015.pdf

Gerőcs, Tamás, To be Bravely Critical of Reality: an interview with Tamás Szentes, in: Review of African Political Economy, 8.11.2018. roape.net/2018/11/08/to-be-bravely-critical-toreality-an-interview-with-tamas-szentes/

Harlow, Barbara, „Flushed with elation“: Ruth First at the University of Dar es Salaam, 22.9.2009. pambazuka.org/governance/flushed-elation-ruth-first-university-dar-essalaam

Jureit, Ulrike, Generation, Generationalität, Generationenforschung, Version: 1.0, in: Docupedia-Zeitgeschichte, 11.2.2010. docupedia.de/zg/Generation

Kappel, Robert Deutschlands neue Afrikapolitik vor dem Aufbruch, in: GIGA Focus 1/2017. gigahamburg.de/en/system/files/publications/gf_afrika_1701.pdf

Lindenberger, Thomas, Eigen-Sinn, Herrschaft und kein Widerstand, Version: 1.0, in: Docupedia-Zeitgeschichte, 2.9.2014. docupedia.de/zg/lindenberger_eigensinn_v1_2014

Nieswand, Boris, Transferring and Transforming Economic Capital. Transnational Migration, Border Effects and Social Inequality in Southern Ghana, 2013. academia.edu/23267259/ Transferring_and_Transforming_economic_capital._Transnational_migration_border_effects_and_social_inequality

Oltmanns, Reimar, Malawi - weiße Herrenmenschen oder Gelder, die im Busch verschwinden, in: Stern, 28. März 1974 (adaptiert). reimaroltmanns.com/2008/05/rmpler.html

Premji, Zulfiqarali, Opinion: The Culture of Sitting Allowances in Tanzania, in: The Citizen/ AllAfrica, 5.1.2017. allafrica.com/stories/201701060363.html

Schneider, Leander Visions of Tanzanian Socialism, in: Jacobin, 12.8.2015. jacobinmag.com/ 2015/12/julius-nyerere-tanzania-socialism-ccm-ukawa/

Unger, Corinna R., Histories of Development and Modernization: Findings, Reflections, Future Research, in: H-Soz-Kult, 9.12.2010. hsozkult.de/literaturereview/id/forschungsberichte1130

URT, National Five Year Development Plan 2016/17 - 2020/21, 30.3.2016. mof.go.tz/mofdocs/ msemaji/Five\%202016_17_2020_21.pdf 


\section{Interviews}

Einige tansanische InterviewpartnerInnen wiesen auf Faktoren wie den tansanischen Geheimdienst hin und baten ausdrücklich um Diskretion. Der Wunsch nach Anonymisierung wurde auch von einigen deutschen InterviewpartnerInnen vorgebracht. Daher wurde - abgesehen von den ersten, noch explorativen Interviews - im Vorhinein eine Anonymisierung zugesichert. In den Fußnoten ist nur die für die Interviewaussage jeweils relevante Position, die damals eingenommen wurde (z. B. GTZ-Experte) angeben; hier der Beruf entsprechend Ausbildung und Karriereweg (z. B. Volkswirt).

Es werden auch die Interviews aufgeführt, die nicht in den Fußnoten zitiert werden. Relevante Informationen zur Biografie oder Position (bzw. im Falle von Gruppengesprächen die Angabe, welche der Personen zitiert wird) sind in der jeweiligen Fußnote enthalten. Die Bezeichnung „tansanisch“, „westdeutsch“ oder „ostdeutsch“ bezieht sich auf die Zeit vor 1990. Mit Klarnamen angegeben sind lediglich jene Personen, die in repräsentativen bzw. Funktionärsfunktionen tätig waren und keine Anonymisierung verlangt haben. Die Kennzeichnungen hinter der fortlaufenden Nummer geben Zusatzinformationen zur Interviewführung:

* Interview gemeinsam mit Berthold Unfried geführt

** Interview geführt und/bzw. zur Verfügung gestellt von Berthold Unfried

$\star \star \star$ Interview gemeinsam mit Atuswege Burton geführt

\#1* Tansanischer Jurist (Dar es Salaam, 18.3.2014)

\#2* Tansanischer Historiker (Dar es Salaam, 18.3.2014)

\#3* Tansanischer Geograf (Dar es Salaam, 20.3.2014)

\#4* Tansanischer Ingenieur (Dar es Salaam, 20.3.2014)

\#5 Tansanische Bibliothekarin (Dar es Salaam, 21.3.2014)

\#6* Westdeutsche Sozialwissenschaftlerin (Tanga, 23.3.2014)

\#7* Tansanischer Entwicklungsplaner (Tanga, 23.3.2014)

\#8 Westdeutsche Sozialwissenschaftlerin (Tanga, 24.3.2014)

\#9* Tansanischer Pädagoge (Tanga, 26.3.2014)

\#10 Tansanischer Politikwissenschaftler (Dar es Salaam, 27.3.2013)

\#11 Tansanischer Soziologe (Dar es Salaam, 27.3.2014)

\#12 Tansanischer Schriftsteller (Dar es Salaam, 27.3. 2014)

\#13 Zwei tansanische Landwirtschaftsberater (Lushoto, 28.3.2014)

\#14 ${ }^{\star \star} \quad$ Tansanischer Jurist (Dar es Salaam, 28.3.2014)

\#15 Tansanische Sozialanthropologin und Gesundheitsberaterin (Dar es Salaam, 28.3. 2014)

\#16 Tansanischer Entwicklungsplaner (Dar es Salaam, 29.3. 2014)

\#17 Ostdeutscher Pädagoge (Potsdam, 24.4.2014)

\#18 Westdeutsche Pädagogin (Berlin, 25.4.2014)

$\# 19$ \#ansanischer Ingenieur (Wien, 7.7.2014)

\#20 Ostdeutscher Jurist (Halle/Saale, 17.7.2014)

\#21 Ostdeutscher Ökonom (Leipzig, 17.7. 2014)

\#22 Westdeutsches Ehepaar, Pädagogen (Berlin, 23.7. 2014)

\#23 Ostdeutscher Journalist (Schöneiche bei Berlin, 29.7.2014)

\#24 Ostdeutsches Ehepaar, Diplomat und Pädagogin (Berlin, 1. 8. 2014)

\#25 Westdeutscher Ökonom (Seeheim-Jugenheim, 13.9.2014) 
\#26 Westdeutscher Ingenieur und westdeutscher Agrarwissenschaftler (Seeheim-Jugenheim, 13.9.2014)

\#27 Westdeutscher Ökonom (Seeheim-Jugenheim, 14.9.2014)

\#28 Westdeutscher Ökonom (Seeheim-Jugenheim, 14.9.2014)

\#29 Ostdeutscher Soziologe (Leipzig, 17.9.2014)

\#30 Ostdeutscher Ökonom (Grimma, 18.9.2014)

\#31 Ostdeutscher Ökonom (Leipzig, 19.9. 2014)

\#32 Tansanischer Geologe (Dar es Salaam, 6.10.2014)

\#33 Tansanischer Ingenieur Awadhi Mawenya (Dar es Salaam, 7.10. 2014)

\#34 Tansanischer Literaturwissenschaftler (Dar es Salaam, 7.10. 2014)

\#35*** Tansanischer Arzt (Dar es Salaam, 8.10.2014)

\#36*** Tansanischer Arzt (Dar es Salaam, 8.10.2014)

\#37 Westdeutscher Journalist (Dar es Salaam, 9.10.2014)

\#38 Tansanischer Fahrer (Dar es Salaam, 9.10.2014)

\#39 Tansanischer Politiker Pius Msekwa (Dar es Salaam, 9.10.2014)

\#40 Tansanischer Ingenieur (Dar es Salaam, 9.10.2014)

\#41 Tansanischer Umweltsoziologe (Dar es Salaam, 10.10.2014)

\#42 Tansanischer Ökonom (Dar es Salaam, 13.10.2014)

\#43 Tansanischer Agrarwissenschaftler (Dar es Salaam, 13.10.2014)

\#44*** Tansanischer Ingenieur und tansanischer Community Development-Experte (Tanga, 14.10.2014)

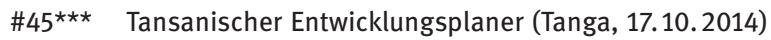

\#46 Tansanische Sekretärin (Tanga, 17.10.2014)

\#47 Tansanischer Literaturwissenschaftler (Tanga, 17.10. 2014)

\#48*** Tansanischer Arzt (Tanga, 18.10.2014)

\#49 Westdeutsche Sozialwissenschaftlerin (Tanga, 19.10.2014)

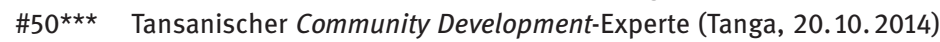

\#51 Tansanischer Techniker (Tanga, 21.10.2014)

\#52*** Tansanischer Entwicklungsplaner (Lushoto, 24.10.2014)

\#53*** Tansanischer technischer Zeichner (Lushoto, 24.10.2014)

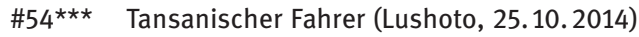

\#55*** Tansanischer Förster (Lushoto, 25.10.2014)

\#56*** Tansanischer Agrarwissenschaftler (Lushoto, 26.10.2014)

\#57*** Tansanischer Techniker (Lushoto, 27.10.2014)

\#58*** Tansanische Agrarexpertin (Lushoto, 27.10.2014)

\#59 *** Tansanischer Raumplaner (Lushoto, 28.10.2014)

\#60*** Tansanischer Entwicklungsplaner (Lushoto, 28.10.2014)

\#61*** Tansanischer Landwirtschaftsberater (Lushoto, 30.10.2014)

\#62 ${ }^{\star \star *}$ Tansanische Geschäftsfrau (Dar es Salaam, 4.11.2014)

\#63 Tansanischer Agrarwissenschaftler (Dar es Salaam, 6.11. 2014)

\#64 Tansanischer Agrarwissenschaftler (Dar es Salaam, 7.11. 2014)

\#65 Tansanischer Agrarwissenschaftler und ostdeutsche Verwaltungskraft (Dar es Salaam, 10.11.2014)

\#66 Tansanischer Volkswirt (Dar es Salaam, 10.11.2014)

\#67 Tansanischer Ingenieur (Dar es Salaam, 10.11. 2014)

\#68 Westdeutscher Pharmazeut (Dar es Salaam, 11.11.2014)

\#69 Tansanischer Ingenieur Awadhi Mawenya (Dar es Salaam, 11.11. 2014) 


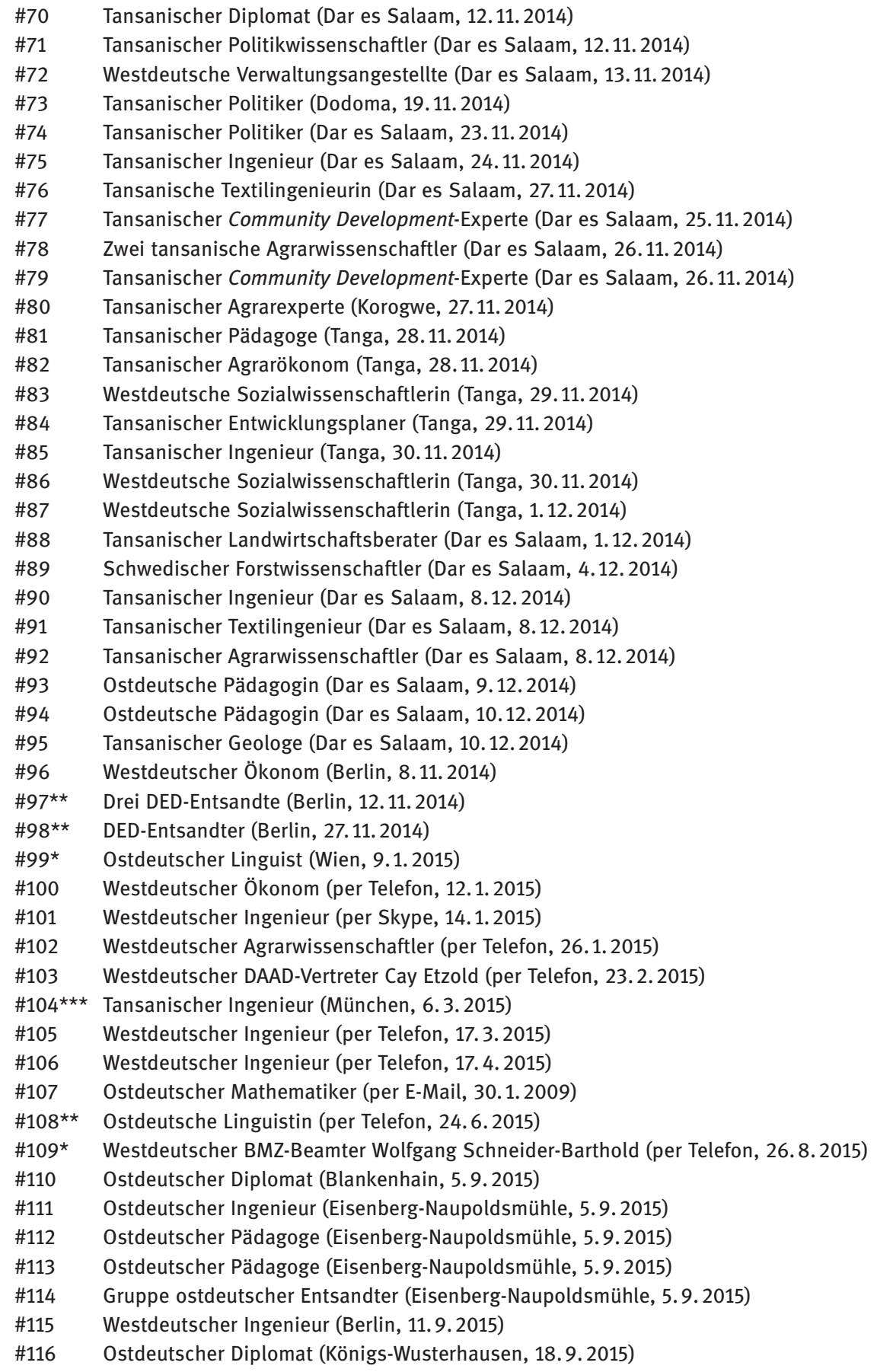


\#117 Ostdeutscher Landwirt/Pädagoge (per Telefon, 22.12.2015)

\#118 Ostdeutscher Politökonom (Berlin, 29.12.2015)

\#119 Zwei ehemalige FDJ-Entsandte, ein ehemaliger FDJ-Funktionär (Strausberg-Nord, 29.12.2015)

\#120*** Tansanischer Ingenieur (Wien, 11.1. 2016)

\#121 Ostdeutscher Politökonom (per Telefon, 4.3.2016)

\#122 Westdeutscher Ingenieur (per Telefon, 19.7.2016)

\#123 Westdeutscher Ingenieur (per Telefon, 8. 8.2016) 